Pre-print for the article:

Gould, R.K., Pai, M., Muraca, B., Chan, Kai M.A.. 2019. "He 'ike 'ana la i Ka Pono (It Is a Recognizing of the Right Thing): How One Indigenous Worldview Informs Relational Values and Social Values."

Sustainability Science 14 (5): 1213-32.

https://link.springer.com/article/10.1007/s11625-019-00721-9

\title{
He 'ike 'ana ia i ka pono (It is a recognizing of the right thing): How one Indigenous worldview informs relational values and social values
}

\author{
Rachelle K. Gould \\ University of Vermont \\ 81 Carrigan Drive, Burlington, VT 05401, USA \\ Corresponding author: rgould@uvm.edu, 8026565849 \\ Māhealani Pai \\ Kamehameha Schools, University of Hawai'i \\ 78-6831 Ali'i Drive \#429, Kailua-Kona, HI 96740, USA \\ Barbara Muraca \\ University of Oregon, Department of Philosophy \\ 1585 E 13th Ave., Eugene, OR 97403, USA \\ Kai M.A. Chan \\ Institute for Resources, Environment and Sustainability, University of British Columbia \\ 2202 Main Mall, $4^{\text {th }}$ floor, Vancouver, BC, V6T 1Z4, Canada
}


He 'ike 'ana ia i ka pono (It is a recognizing of the right thing):

How one Indigenous worldview informs relational values and social values

\section{Abstract}

The ideas of relational values and social values are gaining prominence in sustainability science. Here, we ask: how well do these value conceptions resonate with one Indigenous worldview? The relational values concept broadened conceptions of values beyond instrumental and intrinsic values to encompass preferences and principles about human relationships that involve more-than-humans. The social values concept, an umbrella idea, captures a plurality of values related to society and the common good. After a general description of these two concepts as expressed in the Western peer-reviewed literature, we adopt the lens of relational values to engage with decades of scholarly work and millennia of wisdom based on Indigenous Hawaiian worldviews. We describe five long-standing Hawaiian values that embody notions of appropriate relationships, including human-ecosystem relationships: pono ( $\sim$ righteousness, balance); ho'omana ( $\sim$ creating spirituality); mālama ( care); kuleana ( $\sim$ right, responsibility); aloha ( love, connection). We find that all five resonate deeply with, and help to enrich, relational value concepts. We then draw on these Hawaiian values to discuss differences between relational values and social values frameworks; though the two concepts both add useful elements to the discourse about values, the relational values concept may be particularly well positioned to represent elements often important to indigenous worldviews - elements such as reciprocity, balance, and extension of "society" beyond human beings. As global processes (e.g., IPBES) commit to better reflecting Indigenous and local knowledge and embrace diverse value concepts as (purported) avenues toward representing values held by diverse communities, our study suggests that relational values offer special promise and a crucial contribution.

\section{Keywords}

cultural ecosystem services, decolonial thought, ethics, Hawai'i, Hawaiian, non-Western, Polynesia, shared values, shared social values 


\section{Introduction}

\section{"For history may fade, rituals may be discarded, and customs changed with the passage of time. Yet many of the basic values of Hawai'i's past remain vital and true and applicable in the present day. To these values I hope I have done justice."}

(Pukui et al. 1972, p. 10)

The $21^{\text {st }}$ Century is marked by ongoing escalation of environmental pressures, continued human dependence on ecosystem services, and blossoming recognition of human responsibilities to that which surrounds us. In this context, a plethora of values concepts have emerged in attempts to express, and incorporate into equitable decision-making, diverse concerns regarding nature (Tadaki et al. 2017). In particular, concepts of relational values and social values increasingly enter into conversations and research related to sustainability science. Scholars have worked to clarify these concepts and apply them in different contexts (Kenter et al. 2015; Chan et al. 2016; Pascual et al. 2017). These concepts have important connections to myriad threads of past thinking and other relevant work, and elucidating these connections is crucial to a rich interdisciplinary study (Gaston et al. 2018; Stålhammar \& Thorén, this issue; Massenburg, this issue).

Underdeveloped connections exist both for theory within the Western literature, and with philosophical work and development that transcend formal Western academic approaches. NonWestern, and particularly Indigenous, conceptions of how interactions with ecosystems matter to people heavily influenced the development of the relational values concept (numerous authors of the idea connect with Indigenous research), and one intention (or aspiration) of the relational values concept is to offer possible languages to express diverse human-nature relationships, including Indigenous and local relational cosmologies, in ways that are understandable within decision-making contexts. Yet scholars have not deeply or thoroughly explored the links between recent Western concepts of relational values and non-Western approaches to values. This paper adds to the still-small body of scholarly work that inquires: how does relational values, as a new lens for understanding value, fare in its aim to help express ideas that are meaningful to Indigenous communities (Saxena et al. 2018; Sheremata 2018)?

We focus our analysis on intersections between relational values and one particular set of Indigenous worldviews: Hawaiian worldviews. We ask: How well do a subset of Hawaiian values resonate with relational values approaches? How do our findings illuminate discussions about relational values and social values? What might Hawaiian approaches to values, and the ways they are manifest, understood, and negotiated, have to teach about ways of understanding and negotiating values? We consider the relational nature of social values, the social nature of relational values, and how one particular Indigenous approach interacts with and informs these ideas. We focus our analysis on Hawaiian worldviews and relational values, for reasons described below, and offer introductory and concluding thoughts on connections with social values.

To situate our particular analysis within a larger conversation about Indigenous perspectives, we first address a few points about Indigenous worldviews more generally and how they relate to sustainability science discourses. 


\subsection{Indigenous and Local Knowledge}

\subsubsection{Role in sustainability science discourses, including this paper}

In the past few decades, several prominent international processes have recognized the crucial role that Indigenous and local knowledge and worldviews play in sustainability-related research and practice. The two most recent examples are the Intergovernmental Platform on Biodiversity and Ecosystem Services and the Convention on Biological Diversity, both of which have specific panels or sections focused on better integrating these perspectives, particularly Indigenous perspectives, into their efforts. Scholarly work engages with these efforts, underscores their importance, and suggests tools and considerations for improving their integration. Some scholars describe the necessity of placebased research, in which Indigenous perspectives play an important role, and suggest opportunities to increase the effectiveness of place-based research-e.g., fostering networks to connect multiple sites (Balvanera et al. 2017). Others present processes to facilitate integration that fully respects the depth and sovereignty of multiple knowledge systems (Tengö et al. 2014, 2017).

We hope that our work can contribute to fruitful dialogue between concepts used in the academic literature and concepts from Indigenous and local knowledge systems; part of this dialogue involves acknowledgement that in the encounter between different worldviews, equivocation is an integral part of the process, and cannot (and should not) be resolved (Viveiros de Castro 2004b; de la Cadena 2018). In particular, we believe that a perspective on relational values and social values theory that is respectful of difference must engage with different ontologies and include Indigenous as well as other non-Western approaches. With the present paper, we draw on Native Hawaiian knowledge to contribute to the theoretical basis for relational and social values concepts, with two related goals: to understand how one Indigenous perspective interfaces with relational values and, to a lesser extent, social values concepts; and to better incorporate Indigenous perspectives into sustainability discourse.

\subsubsection{Common threads}

A primary motivation for the recent introduction of relational values concepts into the sustainability discourse was to find languages to facilitate decision-making that reflects the diverse ways in which people, and in particular people from Indigenous and non-Western communities, articulate what matters to them with respect to human-nature relationships (as they are called from a Western perspective) (Muraca 2016; Himes and Muraca 2018). Many Indigenous authors discuss principles of diverse Indigenous worldviews that resonate strongly with relationality and relational values concepts, both in terms of general frames and specific articulations. Below we discuss multiple interrelated themes that appear in these scholarly discussions. We focus primarily on literature from North American and Hawaiian Indigenous scholars, though we mention indications that the principles might apply beyond these geographic boundaries. We recognize that there is no one "Indigenous worldview;" on the 
contrary, there are likely as many such worldviews as there are Indigenous groups (and even having one term to describe all such groups is problematic (Peters and Mika 2017)). Despite this heterogeneity, Indigenous scholars have identified the themes below as common to several Indigenous worldviews.

The idea of dynamic balance emerges in many descriptions of Indigenous worldviews. Tink Tinker, a scholar of Native American (Osage) ancestry, describes how many Indigenous worldviews situate "cosmic/holistic harmony and balance as the ultimate ideal or goal of all human activity" (Tinker 2015, p. 3); crucially, this balance involves both human and more-than-human entities. The idea of a dynamic balance in a sense that transcends the individual connects strongly to the Hawaiian concept of pono, as described below (Chun 2011).

Another common theme is that sentience, consciousness, and kinship extend beyond the human world - that other beings are part of the family (King 1990). Robin Kimmerer, a botanist of Native American (Potawatomi) ancestry, repeatedly refers to plants as beings with their own form of intentionality. She describes the close kin-based connections that numerous Native American communities have with their plant relatives (Kimmerer 2013). Kyle Whyte, a philosopher also of Potawatomi ancestry, notes that in intellectual traditions of Anishinaabe peoples (a group that includes Potawatomi and multiple other Native American peoples), there is "no privileging of humans as unique in having agency or intelligence, so one's identity and caretaking responsibility as a human includes the philosophy that nonhumans have their own agency, spirituality, knowledge, and intelligence" (Whyte 2018a, p. 127; emphasis original). Tinker makes similar points: "For Indian people, relationship never signaled merely human relationships, but has always been inclusive of all 'people,' from humans to animals, birds, trees, mountains, and even rocks. So when we pray, 'For all my relatives' ... we mean to include all of life and not just next of kin within our own species" (Tinker 2015, pp. 9-10). He claims that people must understand this expanded view in order to appreciate the morality and ethics that govern relationships between humans and ecosystems. These ideas resonate strongly with RV.

Another common thread is what Tinker (2015) labels as a "key worldview difference between" Western and Indigenous cultures (p. 10). He contrasts radical individualism and community-ism: "balance requires a community-ist relational perspective rather than the individualist ideology of eurochristian cultures. ... It is community-ist in the sense that personal balance can only be constituted in the relational context of the community whole" (Tinker 2015, p. 3). Tinker labels this as a fundamental issue of different worldviews - worldviews that are relational vs. atomistic. The relational framework of the relational values discourse attempts to help articulate this perspective, as it stresses the relational constitution of individuals and questions the dualistic separation between nature and society (see Discussion).

Reciprocity, gratitude, and an attitude of giving and receiving gifts are also central to many Indigenous worldviews (Kimmerer 2013). The abundance that ecosystems provide is seen as a set of gifts, and reciprocity for those gifts is important. A common practice is to give whenever you take, in reciprocity and in gratitude to the more-than-human entity and the relationship you have with it (Kimmerer 2013; Tinker 2015). Whyte presents the concept of 'renewing relatives,' which combines the ideas of reciprocity and kinship, and also adds crucial reference to the need to restore broken relationships (Whyte et al. 2015). A focus on reciprocity and gift-giving is common in many Indigenous cultures worldwide; as one prominent indication of its importance, recent discussions about Indigenous and Local Knowledge in IPBES identify this orientation as crucial. The desire to include the concept of 
"nature's gifts" was a primary reason for the reframing of "ecosystem services" as "nature's contributions to people," a term more inclusive of the idea of "nature's gifts" (Pascual et al. 2017; Díaz et al. 2018), albeit not necessarily of the idea of reciprocity. Importantly, in this conception the idea of gift exchange extends beyond the human realm - an extension that is especially important for many Indigenous communities. ${ }^{1}$

Relational approaches to science and knowledge are another important part of many descriptions of Indigenous ways of knowing. Gregory Cajete, a scholar of Native American (Tewa) ancestry, portrays what he calls "Native science" as focusing on connections, cycles, and seeing nature as a teacher (Cajete 1994). Kimmerer advocates an approach focused on relationships and connections rather than the atomized separateness (i.e. reductionism) of much science (Kimmerer 2013). To demonstrate how beings often reach their full potential through relationship, she shares the example of the "three sisters" (corn, beans, and squash). This triad of nutritious crops, which is important to multiple Native American groups, is a powerful example of a three-way symbiotic relationship: The corn stalks provide a trellis on which the beans can grow; the beans fix nitrogen and thus enrich the soil; the squash serves as groundcover and reduces both weed abundance and evapotranspiration from the soil. All three plants thrive when in relationship.

These intertwined perspectives manifest in various ways, and a growing body of psychological research, much of it conducted by Indigenous scholars, reveals these manifestations via multiple creative approaches. Megan Bang, a scholar of Native American (Menominee) descent, and her team have conducted a variety of experiments exploring potential differences between Native American and European American respondents, and have found that people in the two groups often have different perceptions of relationships between humans and ecosystems. Native American respondents, for instance, tend to see ecosystems and humans as less separate than do European Americans (Bang et al. 2007; Medin and Bang 2013). When playing with a forest diorama, Native American children take the perspective of animals more often (Washinawatok et al. 2017); this relates, likely, to seeing these animals more as part of their social group, of seeing less of a divide between people and animals. When asked about the values that are important for their children to "learn about the biological world" and "learn about nature," Native American parents are more likely to mention spiritual, holistic, and traditional values than are European American parents. They are also more likely to discuss how people are a part of nature, whereas European American adults are more likely discuss the need to protect nature (Bang et al. 2007).

The themes above resonate with core aspects of relational values - of seeing porous boundaries between ethical dictates for human and more-than-human aspects of the world. In the next section, we provide detail on theoretical discussions of relational values and social values.

\subsection{Theoretical notes on relational values and social values as value concepts}




\subsubsection{Concept definitions}

Relational values and social values are distinct concepts that researchers developed to address similar ideas; they are unique spotlights that illuminate a field of meaning in overlapping ways. Figure 1 offers a visual representation of this 'unique spotlight' metaphor, and populates the illuminated space with examples following four permutations of social values (according to Kenter et al. (2015)). The two concepts share an important alliance in contesting uni-dimensional forms of value and individual-based valuation approaches, but differ in multiple other ways: they have different intellectual histories; they aim to reconcile research and policy related to those values in different ways; and they have until now been part of largely different conversations. In sum, the relational values discourse presents a way to express things that matter and that are rooted in constitutive relational dynamics and are thus not purely instrumentaland that. The social values discourse addresses how to understand, reflect on, and characterize collective (rather than individual) meaning. We elaborate below.

Figure 1. Relationship between relational values and social values, with social values conceptualized (following Kenter et al. (2015) as a) transcendental (black font); b) generated through social processes (green font); c) other-regarding (purple font); and d) related to benefit to society as a whole(orange font). The metaphor represented in the image can help to describe the relationship between relational values and social values concepts: we can visualize the fields of values and valuation of human-nature relationships as a dark room (to those working in the field, it can feel this way!). Relational values and social values approaches are spotlights that originate from different sources and illuminate the room in different, complementary ways. We see notable overlap in the particular values and value concepts they illuminate, but also ways in which they elucidate concepts differently, and thus help address different issues. Also important to this image is that the two concepts do not fully illuminate the field; there are areas that they collectively fail to encompass. 


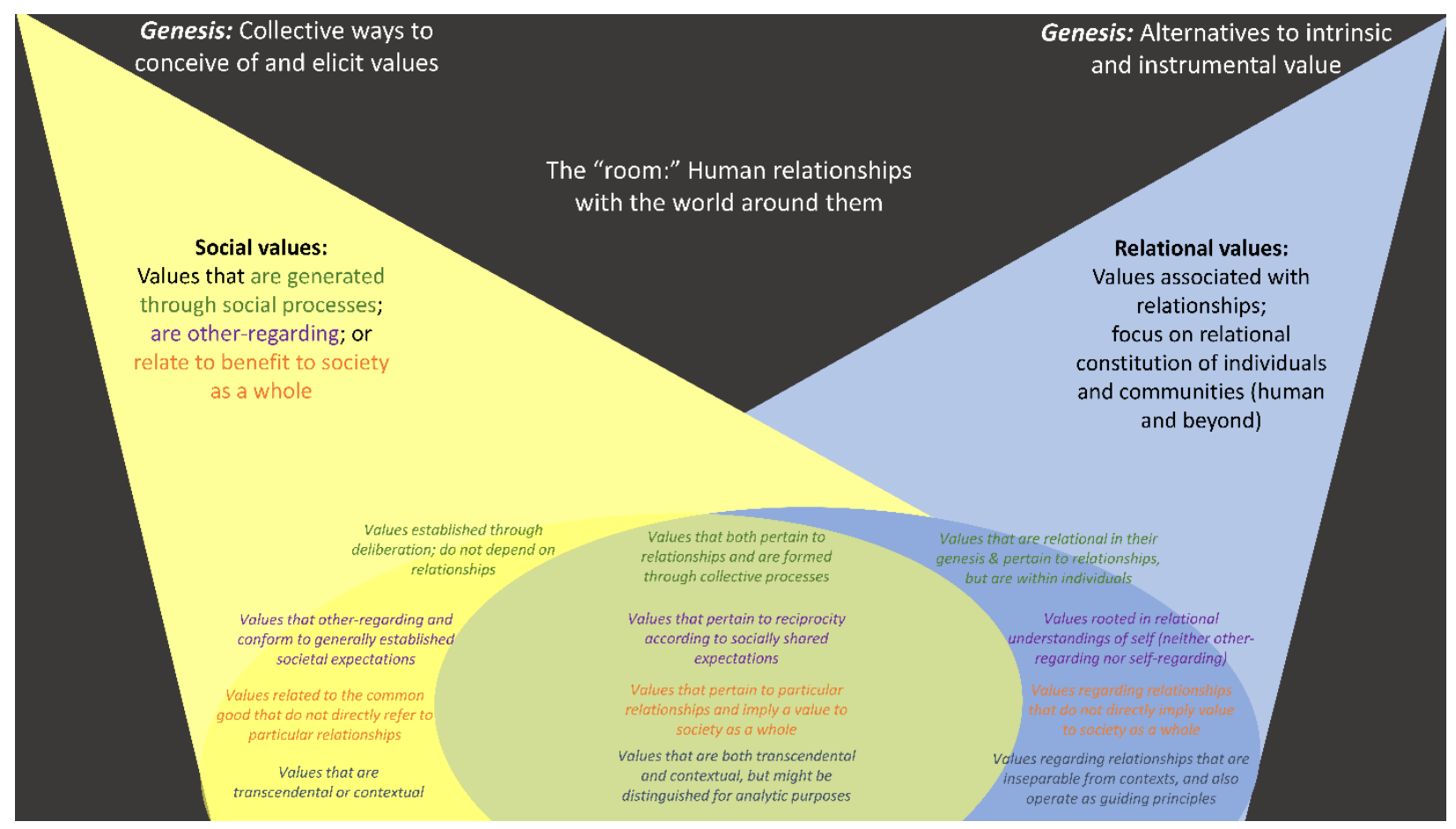

There are multiple recent interpretations of the relational values concept, and they are not all consistent (e.g., Arias-Arévalo et al. 2017; Stålhammar \& Thorén, this issue). We ascribe to the conceptualization lead by Muraca, Chan, and Pascual (and in which the first author of this paper has participated) (Muraca 2016; Chan et al. 2016, 2018; Pascual et al. 2017). In this conception, relational values pertain to "preferences, principles, and virtues associated with relationships, both interpersonal and as articulated by policies and social norms" (Chan et al. 2016, p. 1462). They include "... the relationships between individuals or societies and other animals and aspects of the lifeworld (all of whom may be understood as conscious persons), as well as those among individuals and articulated by formal and informal institutions" (Pascual et al. 2017, p. 15).

In this conception, relational values refer to something specific - mostly particular, relevant relationships. Because most relationships that matter are in some way particular, relational values mirror this specificity (Chan et al. 2018). This does not mean, however, that they are narrow in scope. The contents to which relational values are attributed can be as small as a certain rock covered with shellfish, or as large as all living species (toward either of which people might feel, for example, responsibility) (Chan et al. 2018). Relational values can even refer to the web of life (in which people are embedded through relations of, for example, reciprocity and care (Jax et al. 2018)). ${ }^{2}$ This permutation of the relational values idea entered the sustainability and ecosystem services literature (Muraca 2016; Chan et al. 2016) because a dichotomy between instrumental and intrinsic values did not match the 
observed reality of many people's experiences of what matters to them (Gould et al. 2015; Arias-Arévalo et al. 2018; Saxena et al. 2018; Sheremata 2018)).

Recent scholarship about social values shares goals, and partially overlaps, with the relational values discourse, even though they emerge from distinct starting points (Figure 1). The social values literature, like the relational values literature, is multilayered, diverse, and under development(Kenter et al. 2015, 2019); we use the term social values to refer to the body of concepts variously termed shared values, social values, and shared social value (Kenter et al. 2015). Also like the relational values framework, the social values approach aims to offer alternatives to mainstream (and particularly economic) tendencies to focus on one-dimensional and individual-based valuation approaches (GómezBaggethun and Martín-López 2015). The social values approach stresses shared dimensions of value and "collective meanings and significance ascribed to natural environments" (Kenter et al. 2015, p. 87).

Kenter et al. (2015) present a classification of social values with the aim of developing the field and strengthening links to decision-making. They "identify five dimensions" of values: "the concept of values, the value provider, the elicitation process, the intention of value, and its scale" (p. 89). They then identify types of social values within each of these dimensions. They name seven types of social values (p. 89) ; four that are particularly relevant to this paper are social values as: transcendental (i.e., transcend specific contexts); deliberated (i.e., result from a deliberation process); other-regarding (as opposed to self-regarding); and related to value to society. ${ }^{3}$

\subsubsection{Relational values and social values, transcendental and/or contextual values}

A first important distinction proposed by social values scholars relates to the first type of social value mentioned above: transcendental values. For social values researchers, the distinction between transcendental and contextual values (the "value concept") is especially meaningful; the categories are similar to held vs. assigned values, but according to Kenter et al. $(2015,2016,2019)$ have important differences. The transcendental/contextual distinction in some ways mirrors the recurring discussion, in many fields, of the "two meanings" of the word values: as guiding principles, or as worth/importance (Anderson 1993). According to Kenter et al. (2015), transcendental values are those that transcend specific situations (overarching "ethics and normative beliefs" (p. 89)), whereas contextual values are specific to particular contexts (specific "attitudes and preferences" (p. 89) related to "worth or importance" (p. 87). Though this distinction can help to highlight for environmental management the importance of "overarching principles that guide our life choices" (Kenter 2016, p. 176), it does not easily apply to relational values. As we will describe below, the Hawaiian "values" we discuss simultaneously contain ideas that can apply to many contexts and have meaning and force that are rooted in the uniquely contextual togetherness - i,e., relationship - between territory, land, place, and their inhabitants.

This interdependent relationship between transcendental and contextual values is well represented in conceptions of $\mathrm{RV}$, which cut across the matrix of transcendental versus contextual

$3 \quad$ Kenter et al. also add with respect to the valuer or, in their language, provider, that social values are cultural, communal and group values. We do not address this dimension in the paper. 
values. Relational values refer to particular/specific relationships, which in the language of Kenter et al. (2015) means that they are dependent on an object of value and are therefore contextual. ${ }^{4}$ Yet, as noted above, they often play the role of guiding principles - which Kenter et al. define as transcendental. Thus in a relational context, values can be simultaneously both transcendental and contextual. This dual role of relational values should come as no surprise, given a constructivist view that values are not pre-existing objects but rather constructs that we use to explain and rationalize what matters and why. In the instance of a person caring for a particular piece of land, that person could simultaneously be guided by the notion that caring for that land is the right thing to do (a guiding principle, a transcendental value) and swayed by benefits derived from land management or stewardship (importance or worth, contextual values). In the context of real relationships, these two notions of value (transcendental and contextual) may often be explicitly and inextricably intertwined.

A brief description of feminist care ethics, the core tenets of which also complicate the transcendental/contextual distinction, may be helpful; we focus on this field partly because it resonates strongly with Indigenous perspectives in ways consistent with the relational values concept. Feminist care ethics describes 'care' not as an abstract principle (a transcendental value that informs specific attitudes or preferences), but as an embodied value that manifests in particular contexts and practices. ${ }^{5}$ Care ethics contests the idea that people prioritize what matters and make moral decisions from an impartial position based on general principles (see Gilligan (1993) and papers in this special issue (Kenter et al. 2019; Rawluk et al. 2019)). Instead, from a care ethics perspective, peoples' moral reasoning is guided by considering the relationships and actual needs of all affected parties (possibly including morethan-humans (Warren 2000)) in particular situations. This particularity may seem to align with the idea of contextual values, but crucially, care can also operate as a guiding principle. When translated into the language of social values and value dimensions, care as a general value orientation - e.g., a transcendental value (Chan et al. 2018) - may help spur caring in particular relational contexts. Yet particular contexts can also give rise to generalized priorities; embodied acts of care - and the contextual values with which they are intertwined - also impact general or transcendental values. The relational value of care thus takes both transcendental and contextual forms, and these forms may derive force from each other.

Indigenous

\section{Methods}

\subsection{The Hawaiian biophysical, social, and academic context}

$4 \quad$ According to Muraca 2016 the subject-object distinction is challenged in a relational framework, as in some cases relationships can be constitutive of what people are.

$5 \quad$ Held suggests we consider care as both practice and as value (Held 2006). 
Hawai' $i$ is an archipelago located in the middle of the Pacific Ocean. A series of eight major islands formed by a volcanic hot spot underneath the ocean floor, it is the most remote landmass in the world. Early Polynesians settled the archipelago over 1000 years ago, and sustained populations of millions of people through practices of fishing (including various forms of active fishery management) and agriculture (staple crops included taro, sweet potato, and breadfruit). Prior to the arrival of Europeans in 1778, inhabitants of the Islands lived in a self-sufficient, highly organized social system, with a refined culture, language, and religion that paralelled the feudal system of ancient European society and evolved into a monarchial form of government called the Hawaiian Kingdom (Sai (Sai 2018). The evolution of its political efforts gave rise to the formalization of over twenty international treaties with other foreign powers to stem the tide of foreign encroachment. In 1843, the British and French governments formally recognized Hawaiian independence. Descendants of missionaries who arrived in the 1820 s participated in the unsuccessful revolution of 1893, which caused the unlawful landing of United States military troops. That confrontation led the way for a series of self-declared governing bodies: a provisional government (1893-1894), the Republic of Hawai'i (1894-1900), the Territory of Hawai' $i$ (1900-1959), and the State of Hawai'i (1959-present). Though Hawai'i is technically identified as one of the 50 United States of America, many scholars and Hawaiian residents consider the archipelago to be under prolonged occupation by the U.S.A. (Sai 2008).

The 1970s have been labelled the "Hawaiian Renaissance," when attention to Native Hawaiian culture blossomed after over a century of European influence and, at times, active suppression (e.g., Hawaiian language was banned in schools into the 1960s). Two events are particularly associated with this time: the building and voyage of Hokule'a, a traditional double-hulled voyaging canoe, and the reclamation of the island of Kaho'olawe, which the U.S. Military had used for testing explosives throughout the early and mid-20th century. Connection to ecosystems (both terrestrial and marine) was central to both of these events, and the language of the movement reflected this. As George Kanahele, a prominent Hawaiian writer of the time, wrote, "the rhetoric of aloha 'āina [love for the land] symbolized the whole movement of going back to the source, listening to our kupuna [elders], finding our roots" (Kanahele 1979, p. np). An important recognition made during this time was a reminder that change is constant, and that a renaissance does not mean taking every aspect of previous culture exactly as it was before. Kanahele wrote that "the Renaissance does not mean a literal rebirth of classical Hawaiian traditions, dances, chants and so forth. To believe otherwise is to make a fetish out of tradition" (Kanahele, 1979, p. np). Importantly, Hawai'i is not alone in this resurgence. Cultural renaissance of this type (though obviously with diverse details) has occurred in multiple other contexts - for instance, in Aotearoa (New Zealand) with regard to Māori culture. The principles arising from the Hawaiian context thus have wide relevance.

In recent decades, cultural revival in Hawai'i has expanded to academia, and Hawaiian scholars are leading thinkers and actors in complex questions related to dismantling the hegemony of Western ways of knowing and bringing other ways of knowing into prominence in scholarly conversations. As one scholar describes, "intellectual sovereignty means that we are not ceding ground to empiricist or other haole [foreign, normally European American] ideas of what counts as knowledge. It is important that we describe our reality..." (Silva 2017, p. 10). Others describe the challenges inherent in this work, such as "the fact that we were trying to tell an Indigenous story in an authentic voice, but also trying to fit that story into the formal publishing conventions that exist in a university setting" (Chun 2011, p. xix). In this 
paper, we do our best to represent a portion of the nuance and complexity of the diversity of Hawaiian conceptions related to what the Western intellectual world calls values. We recognize that we cannot possibly do the ideas full justice in so short a format, and hope this serves an invitation to future discussion and pursuit.

\section{2 "Values" and "nature" in Hawaiian worldviews: acknowledging difference and equivocations}

Our analysis was complicated by the important fact that two of this paper's key concepts values and nature - have no direct translation in the Hawaiian language. Here we describe how we dealt with this issue.

The Hawaiian language does not have words for values, virtue, morals, or ethics. To address this, we draw heavily on the work of Malcolm Nāea Chun (2011), who also deeply considers this translation issue in his work. Chun has worked for many years to collect and create a written record of Hawaiian principles, philosophies, and practices, both currently and in the past. He draws on a mix of personal experience, other scholarly work, and Hawaiian mo'olelo - stories and legends. He uses multiple mo'olelo - in some cases quite lengthy ones - to develop and describe his points about Hawaiian

principles. This mode of communication aligns with Hawaiian ways of communicating about values - the stories demonstrate, but often do not explicitly discuss, values (the centrality of stories as demonstrations of value is far from unique to Hawai'i (McShane 2012)). Chun explicitly discusses how this work interfaces with modern Western concepts of values:

The current emphasis on "values" and the desire to understand what they mean are perplexing from the traditional Native Hawaiian worldview. There are no words in Hawaiian for values, morals, or ethics. This lack is not uncommon in traditional cultures where moral or ethical practices were an integral part of everyday life. However, there are many words for actions and expressions of what people today consider to be values (Chun, 2011, p. 1).

Chun implies that in Hawaiian worldviews, values are demonstrated and embodied in practices, rather than discussed. Yet he notes that there are plenty of words for "actions and expressions" that manifest what Western scholarship might call values. The lack of language for these concepts obviously complicates efforts to identify specific values and how Hawaiian worldviews approach values. This challenge is inherent in any translation, which opens possibilities for reciprocal understanding yet also imperfectly captures original meanings and allows equivocations to exist (Viveiros de Castro 2004a). Chun and other scholars have paved the way to a dialogue, and we follow their example. Chun defines values as "concepts and ideas that are important to a people in defining who they are, what they are doing here, and where they are going" (Chun 2011, p. xxiii). What Chun and others refer to, loosely, as values manifest today in Hawaiian society in multiple ways: "Cultural revival and identification," Chun writes, "have gone beyond academic and intellectual arguments to a reality in communities and families and are now part of the political landscape of the islands" (Chun 2011, p. xxiii). Another set of Hawaiian writers emphasize that ceremonies, practices, and associated knowledge and principles are "not of a 
bygone era because these parts of culture are still valued and practiced" (Kanaka'ole Kanahele and Wise n.d., p. i). A prominent example that is highly relevant to sustainability science is Papakū Makawalu, an emerging body of information that collects traditional knowledge about relationships between humans, spiritual entities, ecosystems, and biophysical cycles (e.g. the water cycle). Papakū Makawalu is one way that Hawaiian viewpoints enter into discussions of natural resources management (Higashi Kanahele 2007). Figures 2-9 below illustrate how these values enter into modern life.

Just as Hawaiian language contains no word for values or virtue, it also contains no word for "nature," in the sense of outdoors (Pukui and Elbert 1986; Chun 2011). The Hawaiian word 'āina is commonly used today to refer to a rich, all-encompassing perception of land and water, and often appears in scholarly discussions of Hawaiian worldviews. 'Āina is often translated as land, but literally means "that which feeds." This literal meaning is most often applied to physical sustenence - land provides humans what they need to physically survive. Yet metaphor, and the fluidity between physical and intangible elements of life that accompanies metaphor, are important in Hawaiian culture, and the deeper meaning of 'āina includes the intangible aspects of feeding. Mehana Vaughan, who conducts community-based research in her home community, powerfully and concisely conveys these multiple meanings of the term 'āina. Land, she writes, feeds humans in multiple ways - physically, emotionally, and spiritually (Vaughan 2014). All of the values that emerged in our inquiry were intertwined with 'āina, so we did not need to filter based on whether or not values were "nature-related."

\subsection{Analysis}

In our analysis, we look to Native Hawaiian authors for their discussion of the concept of values in Hawaiian worldviews. We used a basic version of thematic analysis (Braun and Clarke 2006; Vaismoradi et al. 2013): we collected work from a variety of Native Hawaiian scholars and analyzed it for language pertaining to values, and particularly values associated with relationships (i.e., relational values).

Our specific process was as follows. To create our reading list, we first consulted many Hawaiian colleagues, experts, and advisors, asking each for any resources they might suggest that discuss what in English would be called "Hawaiian values." We acquired all recommended readings. Following these consultations, we added a few additional resources through unstructured searches of both peerreviewed and non-peer-reviewed literature. This process led to a rich variety of sources, and thus allows us to follow advice implied by the traditional Hawaiian saying "'Aohe pau ka 'ike i ka hālau ho'okahi (All knowledge is not taught in the same school)" (Pukui 1997, p. 203).

Next we began coding. As we reviewed these collected works, we sought ideas consistent with the definition of relational values presented in the Introduction. When we came across a concept that might be considered a relational value, we noted it along with relevant associated description and detail. We grouped descriptions of each concept from multiple works. After this initial coding, we reviewed our collections of data from multiple sources about each Hawaiian concept. We compared the collective body of detail about each Hawaiian concept to the concept of relational values. There is inherent complexity in parsing relational approaches from relational values (scholars have used the term "relational approach" to refer to a widening epistemological space within ES conversations, to include, 
for example, constructivist or humanities-based perspectives) (Fish et al. 2016; Stålhammar \& Thorén, this issue); we were careful to follow the conceptualization of relational values described in the Introduction (i.e., that described by Muraca, Chan, and colleagues). For Hawaiian concepts that seemed, based on the collected data, consistent with the relational values concept as we define it, we summarized our results in the Results section.

Below, we represent those principles we found most often, those the authors of reviewed works identified as most important, and those we deemed consistent with the relational values concept. Though there is unavoidable subjectivity in our choices of which principles to present, we think it likely that many scholars, if they undertook the process described above (or a similar process), would produce similar results.

\section{Results - Relational values and Hawaiian worldviews}

\subsection{Hawaiian worldviews and values}

Values are often grounded in worldviews, and our analysis builds from the probability that values associated with Hawaiian worldviews likely reflect those worldviews. Consistent with Tinker's description of key worldview differences between Indigenous and Western cultures (see Section 3), ample research suggests that Hawaiian worldviews, though complex and varied, are fundamentally relational in a way that complicates a society-nature divide. Many of the worldviews that undergird current academic conceptions of value are less relational, more individual, and these worldviews differences are one motivation for both the concept of relational values and this study (Muraca 2016). This grounding in worldviews provides a foundation as we explore "values" as understood in Hawaiian ways of knowing.

Though there may be no word for values per se in the Hawaiian language (see Methods section for details), Hawaiian culture encompasses a rich suite of rights, duties, and responsibilities that define appropriate interaction. Crucially, these standards apply to appropriate interaction with diverse beings human beings, animal beings, plant beings, and other beings (most notably in the Hawaiian context, rocks and clouds). The rules about how to behave are equivalent (or nearly so) for all. These other entities - particularly animals and plants - are part of the 'ohana (family), and values appropriate to govern those relationships should be the same. This inclusion of all beings within one moral frame represents both a substantial break with much traditional Western philosophy, and an important aspect of how Indigenous perspectives inspired, describe, and embody the importance of relational values as a unique concept.

In the following sections, we describe five value-related concepts that emerged from our review, many of which are still commonly used in Hawaiian communities today (Table 1, Figures 2-9).

Table 1. Words that are used, to varying extents, in modern everyday language in Hawai'i. Definitions are from the Hawaiian Dictionary (Pukui and Elbert 1986) unless otherwise noted. 


\begin{tabular}{|c|c|c|c|}
\hline Value & Definition & $\begin{array}{l}\text { Examples from } \\
\text { everyday life }\end{array}$ & $\begin{array}{l}\text { Relationship to transcendental } \\
\text { values (Schwartz 1994; indicated in } \\
\text { quotation marks) }\end{array}$ \\
\hline pono & $\begin{array}{l}\text { Goodness, uprightness, morality, } \\
\text { moral qualities, correct or proper } \\
\text { procedure, excellence, well-being, } \\
\text { prosperity, welfare, benefit, } \\
\text { behalf, equity, sake, true condition } \\
\text { or nature, duty; moral, fitting, } \\
\text { proper, righteous, right, upright, } \\
\text { just, virtuous, fair, beneficial, } \\
\text { successful, in perfect order, } \\
\text { accurate, correct, eased, relieved. }\end{array}$ & $\begin{array}{l}\text { "got pono?" t- } \\
\text { shirts; "Hawai'i } \\
\text { pono" bumper } \\
\text { stickers; Hawai'i } \\
\text { state motto. }\end{array}$ & $\begin{array}{l}\text { "Inner harmony" is related, but } \\
\text { explicitly refers to harmony within an } \\
\text { individual. "A world at peace", } \\
\text { though obviously outwardly oriented, } \\
\text { focuses on a fairly narrow conception } \\
\text { of peace as the absence of war, } \\
\text { rather than a more holistic sense of } \\
\text { balance. }\end{array}$ \\
\hline ho'omana & $\begin{array}{l}\text { Fostering of spiritual power or } \\
\text { sacredness (Chun 2011) }\end{array}$ & $\begin{array}{l}\text { "Mana cards" that } \\
\text { contain Hawaiian } \\
\text { spiritual wisdom }\end{array}$ & $\begin{array}{l}\text { "A spiritual life" is closely connected } \\
\text { with this principle, yet the prefix } \\
\text { "ho'o" denotes action - i.e., the } \\
\text { active creation of sacredness. }\end{array}$ \\
\hline mālama & $\begin{array}{l}\text { To take care of, tend, attend, care } \\
\text { for, preserve, protect, beware, } \\
\text { save, maintain }\end{array}$ & $\begin{array}{l}\text { Signs that read: } \\
\text { Please mālama this } \\
\text { beach. }\end{array}$ & $\begin{array}{l}\text { "Helpful" is related, but has a much } \\
\text { more superficial connotation than } \\
\text { caring. Caring implies a more } \\
\text { extended relationship than helping. }\end{array}$ \\
\hline kuleana & $\begin{array}{l}\text { Right, privilege, concern, } \\
\text { responsibility, title, business, } \\
\text { property, estate, portion, } \\
\text { jurisdiction, authority, liability, } \\
\text { interest, claim, ownership, tenure, } \\
\text { affair, province }\end{array}$ & $\begin{array}{l}\text { Signs that read } \\
\text { "voting is your } \\
\text { kuleana" }\end{array}$ & $\begin{array}{l}\text { "Responsible" is closely related to } \\
\text { part of the meaning of kuleana. } \\
\text { Kuleana, however, also includes the } \\
\text { element of rights, which is not } \\
\text { represented by "responsible." }\end{array}$ \\
\hline aloha & $\begin{array}{l}\text { Love, affection, compassion, } \\
\text { mercy, sympathy, pity, kindness, } \\
\text { sentiment, grace, charity }\end{array}$ & $\begin{array}{l}\text { Aloha 'āina as a } \\
\text { common phrase } \\
\text { seen in media and } \\
\text { popular culture }\end{array}$ & $\begin{array}{l}\text { "Mature love" captures part of the } \\
\text { meaning of aloha, but likely refers to } \\
\text { love between human individuals, } \\
\text { whereas aloha refers to a more } \\
\text { expansive form of love. }\end{array}$ \\
\hline
\end{tabular}

\subsection{Five Hawaiian values that resonate with relational values}

\subsubsection{Pono ( righteousness, balance)}

Pono is, according to many scholars and practitioners, a central concept in Hawaiian worldviews. Pono is a concept that describes how relationships should be (Chun 2011) and thus serves as a strong 
example of a relational value. Pono, as such an important concept, has scores of English definitions, none of which fully capture its meaning. Most definitions, however, share ideas of righteousness and balance.

Pono plays an important role in Hawai'i today. It anchors the state motto ("Ua mau ke ea o ka 'āina i ka pono," translated as "the life of the land is perpetuated in righteousness"). The motto is based on the speech King Kau'ikeaouli Kamehameha III delivered in 1843, when the British government restored power to the Hawaiian Kingdom after five months of occupation. The word is also used in everyday language included in the names or organizations and initiatives, and found on t-shirts, bumper stickers, and advertisements (Figure 8).

Pono is associated with customary norms of ecosystem management in Hā'ena, a community on the island of Kaua'i. Lawa pono, for instance, represents the concept of taking from an ecosystem only what you need (Vaughan et al. 2017, p. 39). In interviews related to management of a nearshore fishery, it was the most frequently mentioned value that guided harvesters. Lawa means "enough, sufficient, ample; to have enough, be satisfied" (Pukui and Elbert 1986), so lawa pono might translate loosely into "taking just enough in accordance with pono - in a balanced, right way." The term lawa pono, and its strong relevance to ecosystem management today, provides an example of how the abstract concept of pono manifests in repeated action.

Ho'oponopono is a practice squarely based on efforts to foster pono. In ho'oponopono, which Chun (2011) defines as "healing to make things right," "the bonds of relationship are primary" (155). He notes that the core of what allows ho'oponopono to function effectively is a set of principles that we identify as relational values: after listing a number of guidelines for the process of discussion and deep listening, he writes that "as much as the above are important tools, they must be guided by a deep emotional understanding based on trust, sincerity, and honesty. Without these guiding principles no amount of discussion and listening will ever lead to any understanding or healing" (Chun 2011, pp. 1589).

A collaborative project to share research about Cultural Ecosystem Services on Hawai'i island provides another example of the centrality of pono. To share findings with the community, researchers and project partners designed a multi-hour hula event and show involving chants and other forms of music (Gould et al. 2014). The partners, a kumu hula and another local community leader, named the show "Pono me ka 'āina: Nau ke koho", which they translated as "Right with the land: The choice is yours". Partners chose the name for the show based on the core message they wanted to send: that the primary concern was to achieve pono, and that people have agency to make that happen. ${ }^{6}$

\subsubsection{Ho'omana ( creating spirituality)}

In the Hawaiian language, ho'o means to make or do. When combined with a noun, it means to make or do that thing. Mana is spiritual energy and power, or sacredness. Thus ho'omana means to make or foster spirituality or spiritual power. Chun presents ho'omana as a central Hawaiian principle,

\footnotetext{
${ }^{6}$ Video footage and information on the show are available at: http://www.uvm.edu/rsenr/rgould/PonoMeKa/ponomekaaina.html.
} 
and Kanahele lists developing mana as a leadership quality (Kanahele 1992). Chun gives a sense of the meaning of spirituality as a virtue associated with relationships by describing how "the relationship with something greater than yourself ... should be the focus of a prayer or ritual" (Chun 2011, p. 170).

The sacred is central to many aspects of Hawaiian worldviews; it is, along with pono, perhaps one of the most central aspects. In a study that collaboratively developed a Cultural Ecosystem Services framework for two place-based communities in Hawai'i, mana (spirituality) was one of four overarching categories of service delineated by community members (Pascua et al. 2017). It was the category with the most subcategories. Ho'omana is one of those sub-categories, and is defined as "spiritual beliefs and practices that allow people to interact with the mana of a landscape" (Pascua et al. 2017, p. 471). Other subcategories include 'aumākua (described below) and kino lau ("presence and recognition of plants, animals, and elements that represent/symbolize Hawaiian dieties") (Pascua et al. 2017, p. 471). Other work on Kaua'i Island similarly found notions of the sacred to be central to, in that case, management of marine resources. "The customary norm of hō'ihi (to cause something to be sacred, to give respect)," the study found, "teaches the importance of maintaining balanced, reciprocal relationships between humans and the environment" (Vaughan et al. 2017, p. 40). Respect, as intertwined with sacredness in the definition of ho' 'ihi, is central to interacting with ecosystems, and many norms and rules embody understanding that fish are "conscious beings that choose whether to be caught" (Vaughan et al. 2017, p. 40).

This understanding of more-than-humans as conscious, choosing beings relates to another component of Hawaiian worldviews, and another way that ho'omana intertwines with ecosystems: 'aumākua. 'Aumākua, ancestors embodied in animals and other more-than-human entities, are a powerful force for many Hawaiians (Figure 2). 'Aumākua are part of one's 'ohana (family). They are familial guardians and ancestors who offer protection and guidance. Their appearance is often associated with reminders of what is important and notable life moments.

Figure 2. 'Aumākua, by Anthony Kekona. Kekona, a Native Hawaiian artist. This artwork depicts the concept of 'aumākua using an image wherein the boundary between human and animal is fluid; the focal point of the piece is a face that is half-human, half-pueo (Asio flammeus sandwichensis, an endemic Hawaiian owl) flanked by a protective shark. The pueo and the manō (shark) are two fairly common 'aumākua. The taro plant (lower left) is seen as the older brother of Native Hawaiians. Reproduced with permission. 


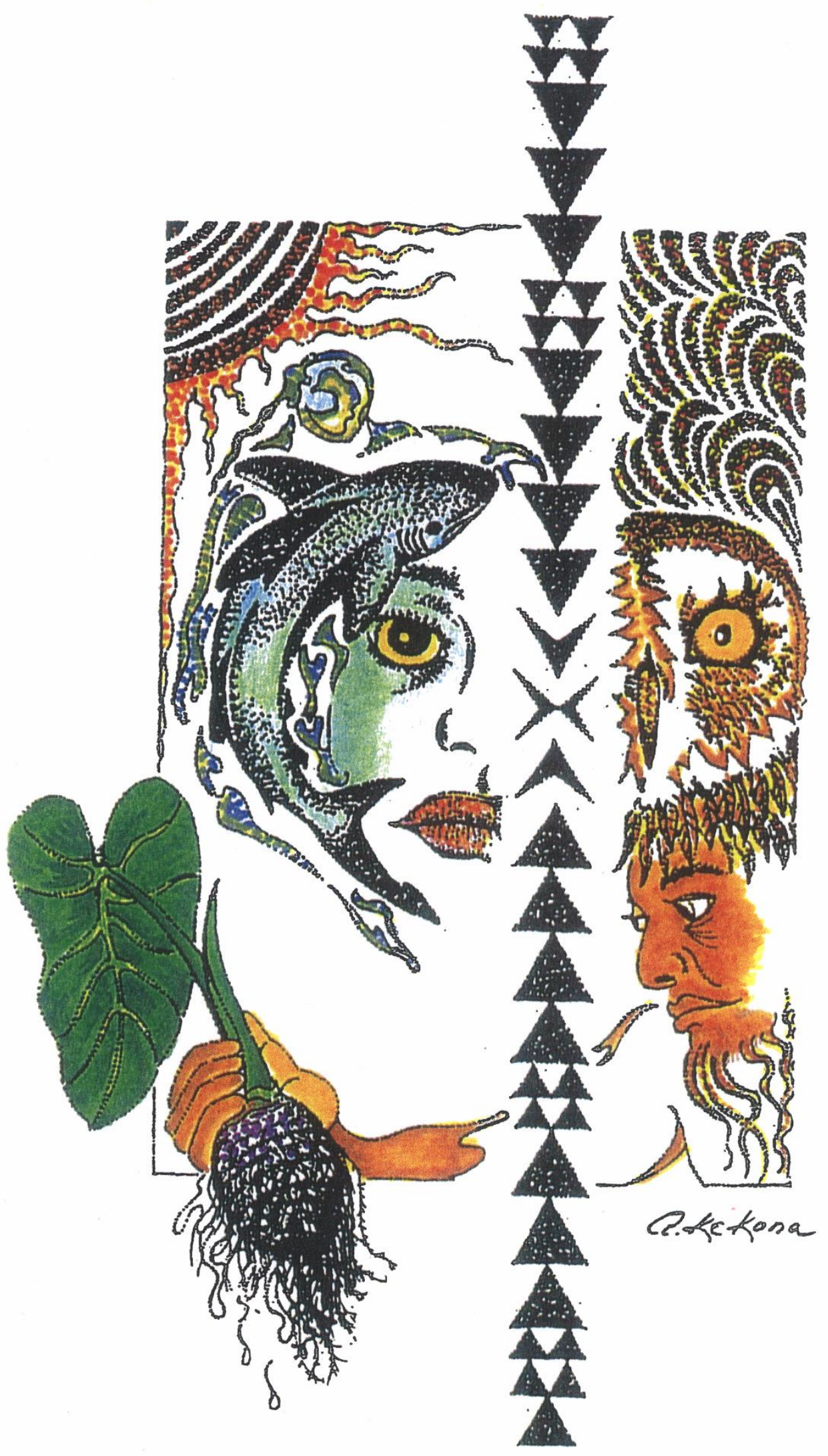


Despite the prevalence of Christian beliefs in Hawai'i, 'aumākua are still discussed and deeply respected. According to Chun (2011), "part of the reason this belief system in the 'aumākua was able to survive [in the face of missionaries bringing Christianity to Native Hawaiians] is the fact that it was not part of the temple worship but ... a relationship that was much closer and more personal" (p. 182). As such, the relationship with 'aumākua is governed by relational values such as respect and caring. Chun (2011) describes "a very real and cherished relationship between a family and their departed relative or ancestor that is maintained through an ancestral symbol or form" - an 'aumakua (p. 184). A

foundational sourcebook of Hawaiian values in the 20th century, Look to the Source (Pukui et al. 1972), describes 'aumākua as a sort of moral police. A Western psychiatrist collaborated in writing Look to the Source, and the publication describes the 'aumākua as seen through his Western intellectual lens:

Dr. Haertig, our psychiatric consultant, sees the 'aumākua concept as including but not limited to functions of the Super Ego or conscience. He says: "It seems important that these are family gods with names. Even though these people are in such dim and distant past that nobody alive ever saw them, yet they seem a somewhat mystical and externalized form of deeply ingrained family traditions, family mores, standards and values (Pukui et al. 1972, p. 48)."

'Aumākua are entities, beings, yet "are experienced as principles, values, standards" (Pukui et al. 1972, p. 48). These values were surely taught by living human relatives (especially elders), the authors suggest, but "it goes beyond that. It is the feeling of a long, shadowy line of ancestors who exercise the [living] seniors' prerogatives of guidance and judgment. It is the actual, felt presence of family" in the form of more-than-human aspects of ecosystems (Pukui et al. 1972, p. 48). As one Hawaiian professional described it, the 'aumākua are related to "a feeling that your ancestors are always here-always with you" (Pukui et al. 1972, p. 48).

Again, 'aumākua are elements of ecosystems, most often animals. As demonstrated by the passages above, in many (if not most) conceptions, 'aumākua are part of the family. And they are important elements of moral education and continual moral check-ins. This familial, kinship-based relationship with more-than-human beings, governed by a complex array of reciprocal duties and values, provides a powerful example of relational values and was an inspiration for the concept of relational values as presented in Chan et al (2016).

\subsubsection{Mālama ( care)}

Mālama is generally translated as care, or to care for. The concept of e mālama i ka 'āina - take care of the land - played an important role during the resurgence of Hawaiian culture in the 1970s, particularly the movement to protect Kaho'olawe, the small island the U.S. military used for target practice (Linnekin 1983). Mālama is one of the primary qualitites of leadership that Kanahele puts forward in his foundational book about Hawaiian values (Kanahele 1992). The concept of mālama, along with that of pono, is central to Hawaiian culture, and the relationship of that culture to ecosystems. These concepts are so central to Hawaiian worldviews, in fact, that a prominent scholar of Hawaiian 
culture, Kepā Maly, named one of his foundational essays "Mālama pono i ka 'āina [balanced, righteous caring for the land] - An overview of the Hawaiian Cultural Landscape" (Maly 2001).

The concept of mālama is still highly prevalent today (Figures 3, 4, and 5). It is understood by most long-term residents, and appears in discourse and signage, particularly as related to the environment (Figures 2 and 4). It emerges repeatedly in scholarship related to peoples' relationship with land in Hawai'i (Gould et al. 2010, 2014; Vaughan and Vitousek 2013; Pascua et al. 2017). The concept is so widely used in Hawai' $i$ today that some generational residents note that many of the people using the term, wanting to mālama 'āina, might not "truly get it" - i.e., might not understand the deeper meanings of the phrase (Gould et al. 2010, p. 448). This likely reflects the nuanced and embedded nature of the concept. It is not something that can be easily translated or understood in a soundbite. It is a value-laden practice intertwined with relationship (i.e., a relational value) and, as noted below in the discussion of kuleana, may take years, or generations, to fully comprehend, internalize, and manifest.

Figure 3. Example of the use of the term mālama ( care) as a directive for how to treat the upland forest (wao kele). Sign produced by the U.S. Fish and Wildlife Service and the State of Hawai'i Department of Land and Natural Resources. Photo by Leah Bremer.

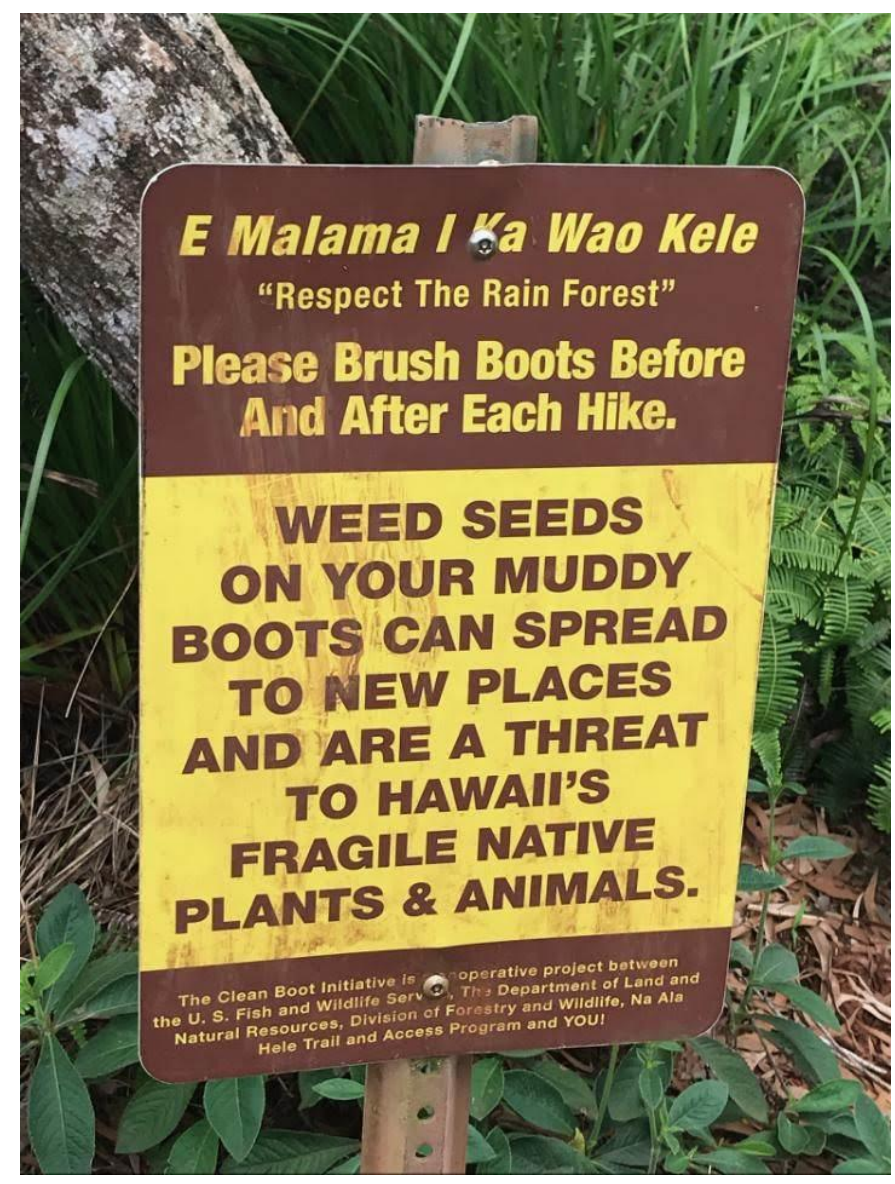

Figure 4. These two signs direct beachgoers to mālama a) the 'āina ( $\sim a n d)$ in general, and also the small beach behind the partition, and b) a larger beach/coastal area named Kiholo. Photos by Rachelle Gould. 

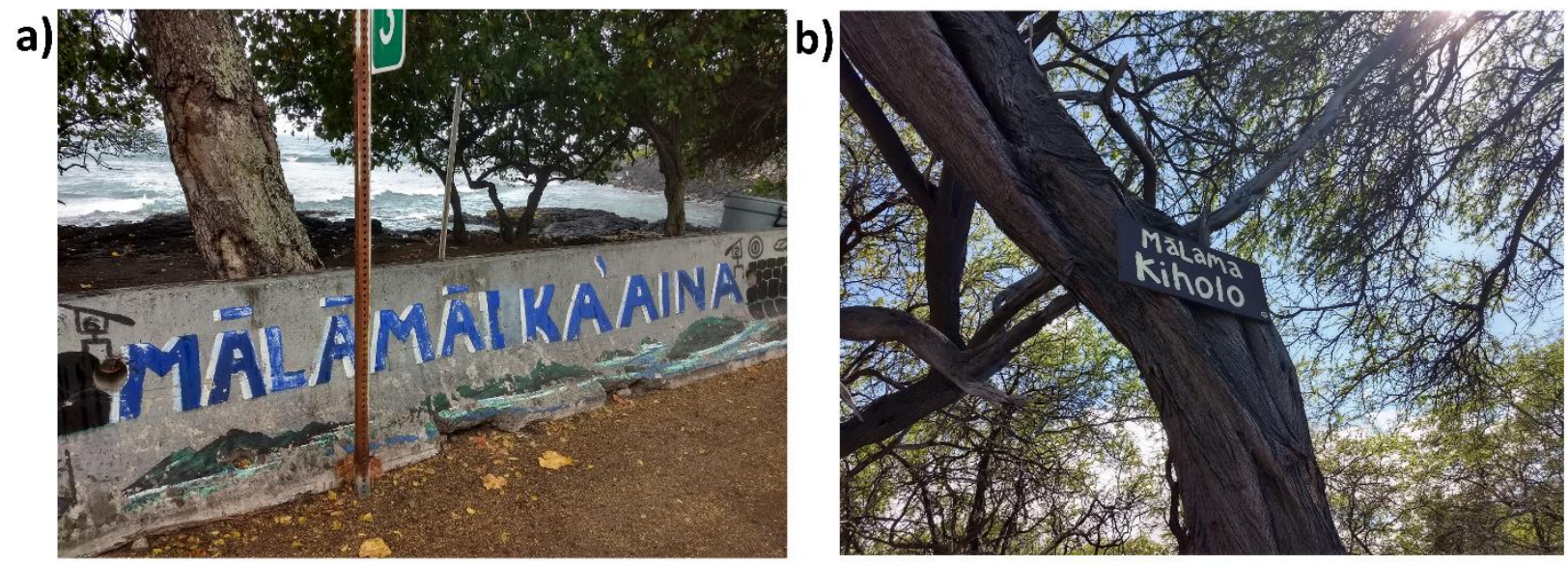

Figure 5. Mālama Hawai'i. This poster produced by the Hawai'i Department of Land and Natural Resources highlights the term mālama ( $\sim$ care). It also references kuleana ( $\sim$ responsibility and right). Photo by Leah Bremer. 


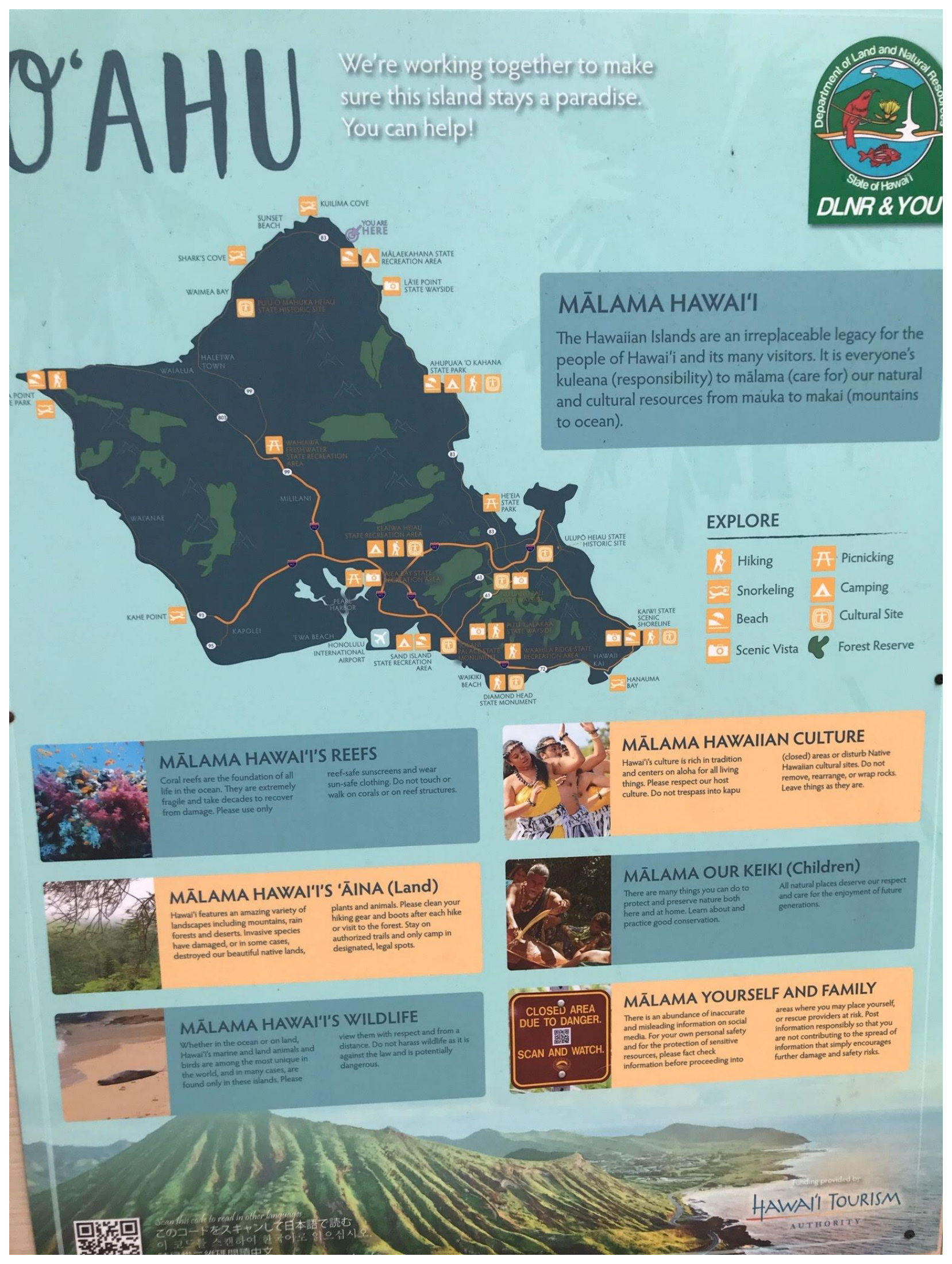




\subsubsection{Kuleana ( responsibilities and rights)}

Kuleana is another term that is part of Hawaiian parlance today (Figures 5 and 6). In English, the word that comes closest to kuleana is responsibility. Yet the Hawaiian concept of kuleana encompasses layers of meaning and nuance not represented by this English word. The most important distinction is that the word kuleana encompasses both rights and responsibilities. Scholars describe kuleana by noting that traditional management norms ascribed people, often family groups, rights to particular land based on responsibilities to that land (McGregor 1996), or "exclusive rights based on responsibilities" (Vaughan et al. 2017, p. 39). Scholars describe how "kuleana deepens and develops over a lifetime and over generations..." (Aikau et al. 2016, p. 162). Today, kuleana remains central "to Hawaiian thinking about land," and land is central to conceptions of kuleana (Aikau et al. 2016, p. 162).

The idea that rights do not exist as separate from responsibilities provides crucial insight and perspective. One cannot have rights without responsibility. With responsibility comes rights. Said another way, "rights are earned only by first fulfilling responsibilities and every right or privilege comes with increasing levels of responsibility (Blaich 2003)" (Nakoa and Wright 2015, p. 15, citation original). Kuleana is fundamentally about nurturing respectful relationships to resources (Vaughan 2018). This dual meaning suggests that relational values must infuse all aspects of management, because you cannot have a right to go to or use something without also having a responsibility to mālama it - to care for and nurture it as you might a human family member. Kuleana can be seen as a relational value because it "encompasses rights, authority, and responsibility, and it suggests a familial relationship" (Silva 2017, p. 4) - thus, the virtues you apply to family also apply to the land.

Figure 6. Bumper sticker that conveys that in a democratic society, the act of voting enacts kuleana. This use of the term provides a good example of the meaning of kuleana as both right and responsibility. Photo by Rachelle Gould.

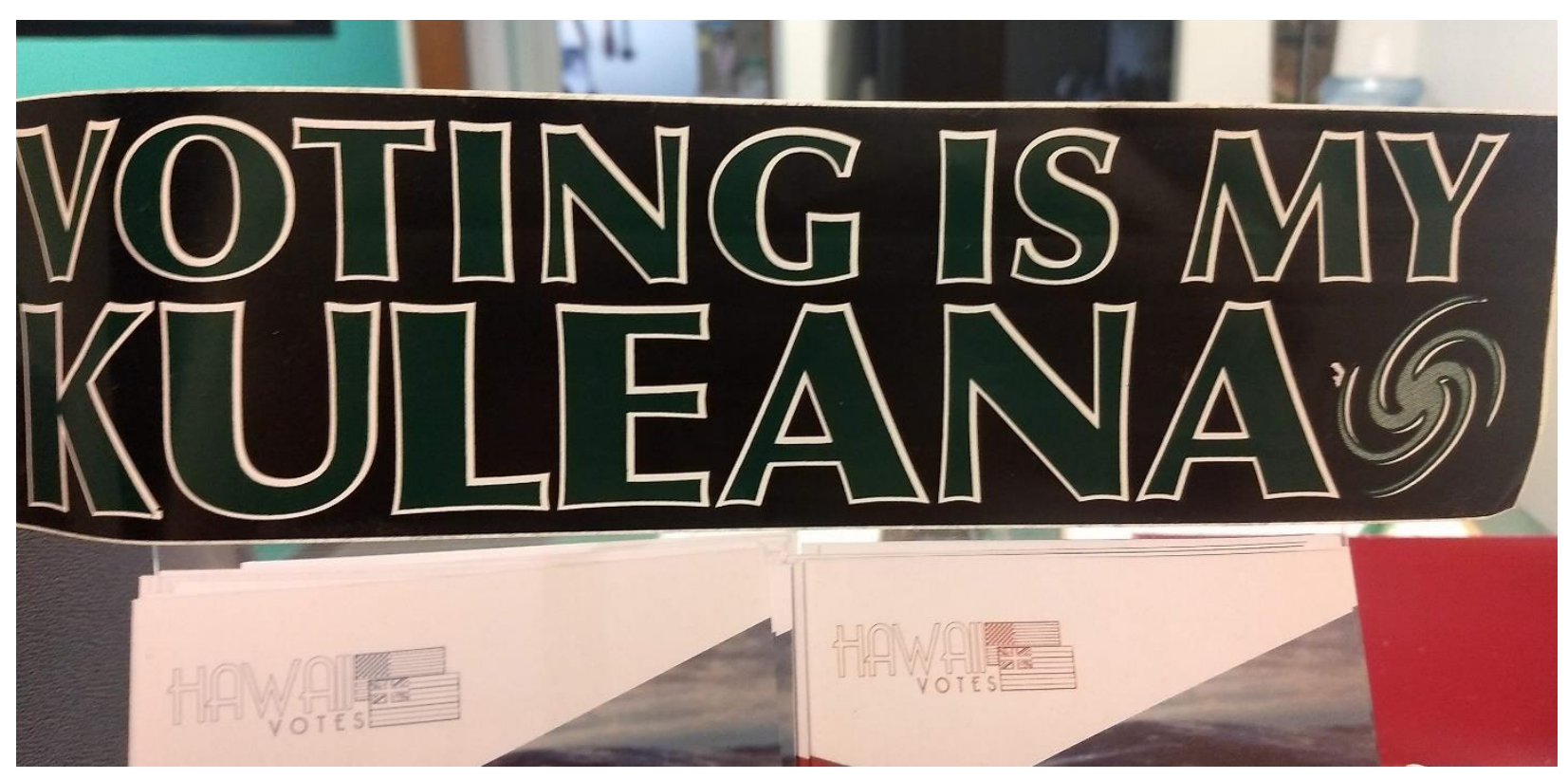




\subsubsection{Aloha ( love, affection, sharing life energy)}

Aloha is likely the most widely known Hawaiian word (Figures 7 and 8). Aloha is commonly translated as love and affection, but its etymology bespeaks a more nuanced significance. Alo means "face or front" and ha means "breath." In Hawaiian worldviews, the breath is an extremely important force; it contains one's mana, or spirit. Aloha thus literally translates as "face to face, sharing breath (/spiritual energy)" - a highly meaningful act.

Figure 7. Aloha beach stewardship box. This box, which is adjacent to the walkway between a parking lot and a beach, provides information, suggestions for stewardship behavior, and physical tools that encourage beachgoers to express aloha. Photo by Rachelle Gould.

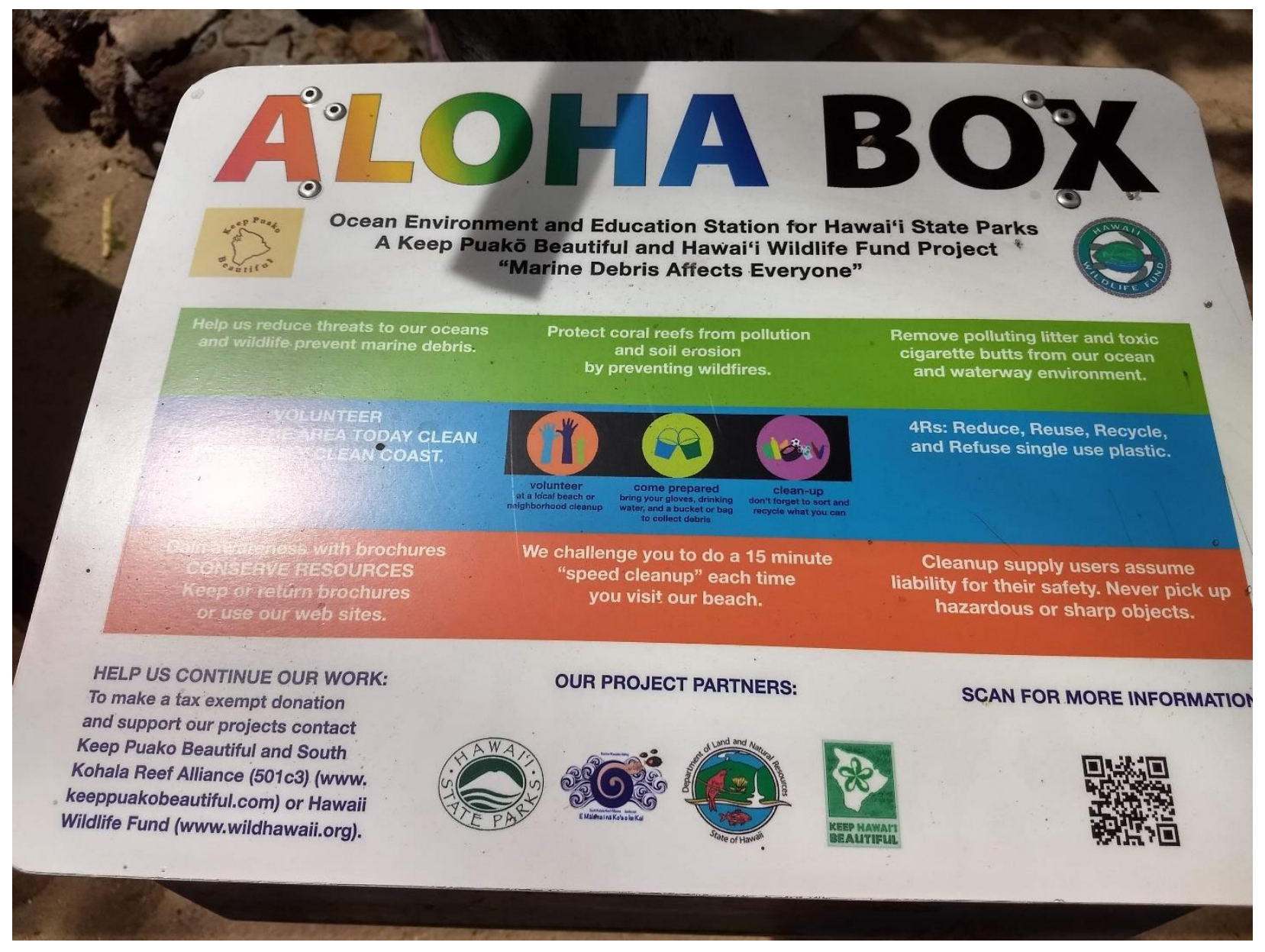

Figure 8. Bumper sticker, Aloha Pono. This sticker conveys the way that the concepts of aloha and pono permeate everyday Hawaiian culture. Photo by Rachelle Gould. 


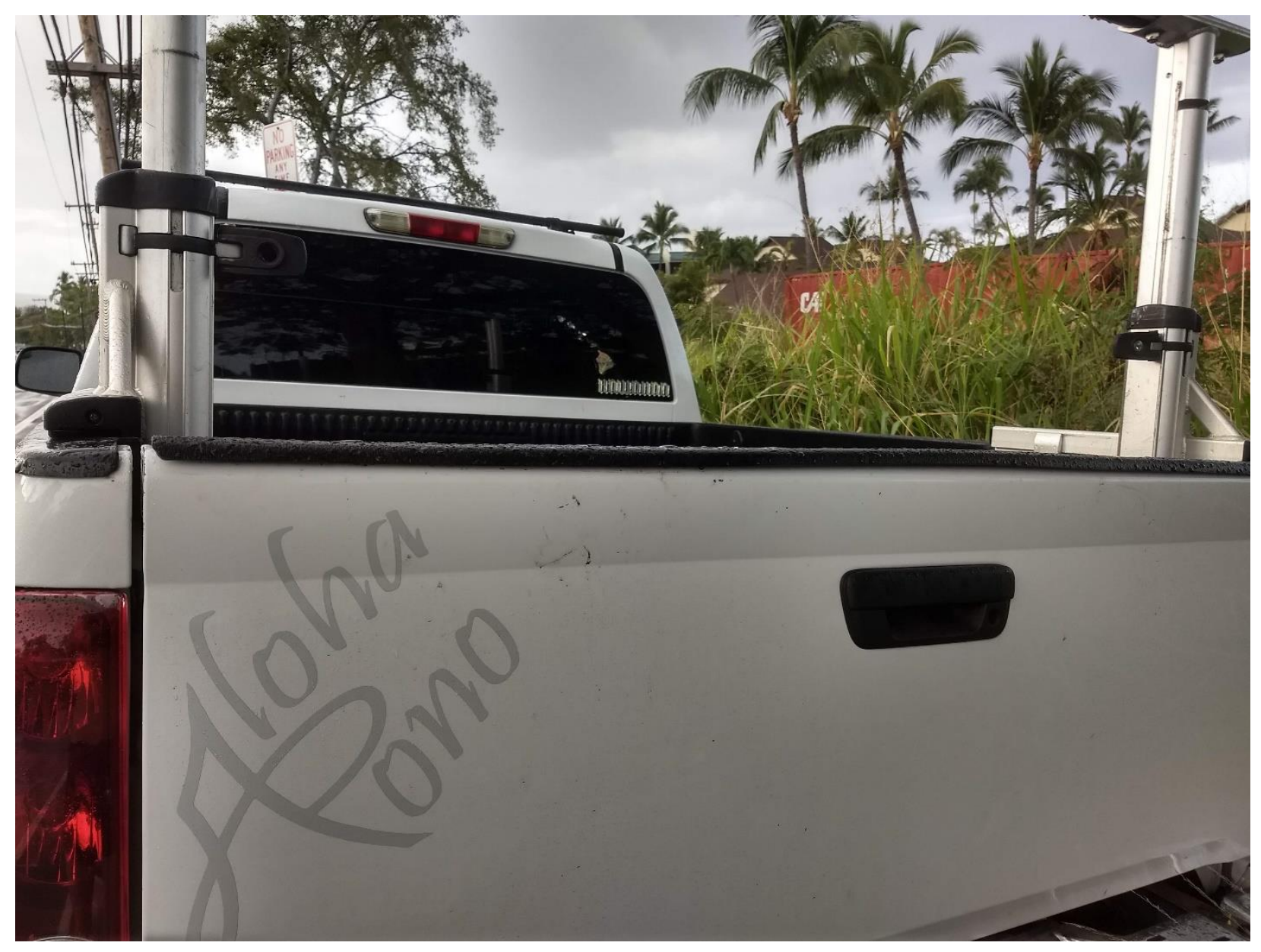

Some scholars suggest that aloha may have historically been less common than current-day popular culture implies. Kanahele says that aloha spirit is one Hawaiian value, but probably not the primary value; aloha has in his opinion been commercialized and politicized. He writes: "Whether we like it or not, aloha has been lifted above its Hawaiian origins, to become as much public property as air and sunshine. Aloha is everybody's prerogative - and should be everybody's gift" (Kanahele 1992, p. 494).

In many ways, the concept of aloha, as scholars currently describe it, embraces many of the ideas in previous sections. In particular, the phrase aloha 'āina is fairly common today, and is related to multiple concepts described above. Aloha 'āina is focused on a loving, affectionate, and vital relationship with land. According to Noenoe K. Silva, it "includes the kuleana [responsibility/right] to mālama or care for the 'āina" (Silv(Silva 2017, p. 4). Silva also writes: "Aloha 'āina is a complex concept that includes recognizing that we are an integral part of the 'āina and the 'āina is an integral part of us. ... Within this idea of aloha 'āina is the concept of kino lau, or multiple physical bodies of spirits" (Silv(Silva 2017, p. 4). Kino lau, as mentioned above in the ho'omana section, are physical manifestations of spiritual beings, and are often particular species (e.g., the palapalai fern (Microlepia strigosa) is one form of Laka, the spiritual force of the forest and hula), but are not specific ancestors, as are 'aumākua. Silva explicitly notes the close family relationships with these elements of nature: "Our familial relationships to these beings are part of our feeling and our ethic of aloha 'āina" (Silva 2017, p. 4). She also notes the relevance 
of aloha to governance: "Aloha 'āina is a central ideology for our ancestors .... and also in our current movements of resurgence. ... [It] is an important political concept" (Silva 2017, 4).

Papakū Makawalu, the emerging body of information mentioned above, also encompasses this idea of the current relevance of traditional concepts (Ka'imipono and Kahumoku 2006). Papakū Makawalu is one lens, or framework, for ancestral knowledge about relationships between humans and the rest of the world. A core part of that knowledge concerns the characteristics of appropriate relationships. The concepts discussed above - pono, ho'omana, mālama, kuleana, and aloha - are some of those characteristics. As numerous scholars discuss, these concepts have deep relevance for presentday environmental management (Kanahele 2009). Figure 9 describes a ceremony held in 2019 that helps to understand one way in which values that govern human relationships with the surrounding world are enacted.

Figure 9. Observation and description of a ceremony performed at the time of the equinox. The ceremony expresses and reminds of the values discussed in this paper. The description presents one perspective. Photo by Māhealani Pai.
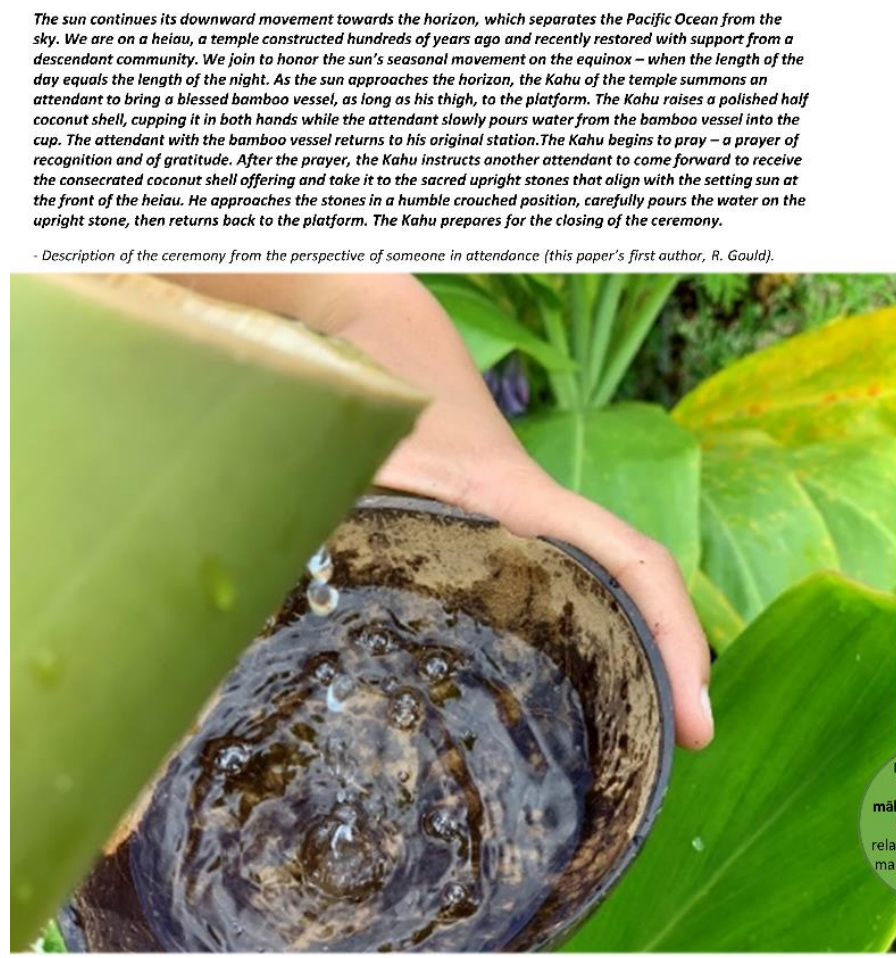

This ceremony enacts the values that govern human relationships with the surrounding world. The ceremony reminds participants of the importance of these relationships and practices that are otherwise often displaced.

$$
\begin{aligned}
& \text { One of the many kino lau (body forms) } \\
& \text { of Kăne (a prominent Hawaliian sacred }
\end{aligned}
$$
of Kăne (a prominent Hawaiian sacred A certain variety of bamboo naturally contains wai (water). They are thus referred to as Käneikawai' ola (the life

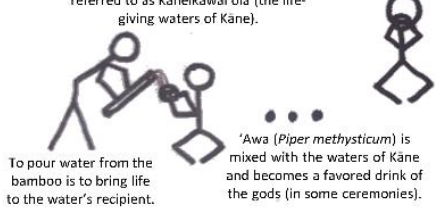
To drink this water provides Earth's nourishment - nourishment born from the elements, the sky, the land, then distributed to feed the population. To not just the Earth's nourishment, but also which life depends and knowledge of the values that govern our relationships.

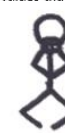

These environmentat, elemental processes - e.g., sunlight, water cycles, plant growth, earthquakes - are humans' elder siblings. They are all interdependent and the ceremony deconstructs them to better appreciate them.

"To understand these processes is to understand and restore our relationship to them. If we do not know all of these processes, how can we cherish and advocate for them?"

The ceremony embodies the Hawaiian values described in this paper in multiple ways.

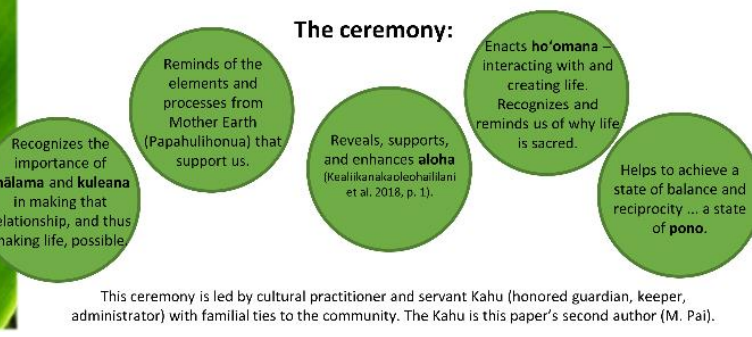

\section{Discussion}

The descriptions above offer one window into Hawaiian worldviews, via five value-like concepts that many see as important to (though far from fully representative of) those worldviews. Our results 
demonstrate that many aspects of Hawaiian worldviews resonate strongly with the relational values concept. We first summarize that resonance and also ways that the relational values concept might be modified or expanded to even better accommodate values such as the Hawaiian values we discuss. We then add social values back into the conversation, and consider how Hawaiian 'value concepts' may inform research on relational values and social values. To conclude, we reflect on how ideas related to Hawaiian conceptions of values may inform sustainability practice.

\subsection{Hawaiian Values and relational values - resonance and areas of expansion}

The five values described above align with many core aspects of the relational values framework. The values are closely intertwined with meaningful relationships. They are neither primarily about benefits that people receive (instrumental), nor about a value of nature in and of itself (intrinsic). They dictate that the same values apply equally to human and more-than-human actors and thus eschew a stark division between humans and more-than-humans. Accordingly, these values may not be adequately represented by more traditional, dominant valuation frameworks in the sustainability science discourse, which often focuses on instrumental or intrinsic values (Tallis and Lubchenco 2014; Batavia and Nelson 2017). As we expected, the relational values concept provides appropriate space for a more nuanced understanding of these values.

Our results also suggest future directions for relational values research. There has been little work on relational values and spirituality, in all of its varied forms, but spirituality is for many communities fundamental to human-ecosystem relationships. It is the focus of one of the Hawaiian values we highlight, and pervades multiple others (e.g., through kino lau, or species that embody particular deities, as discussed in the description of aloha above). Spirituality often concerns links or relationships (Taylor 2010), and the relational values framework could thus further consider the way that spiritual connections manifest in relational values concepts. An additional potential area of growth for relational values scholarship is to consider how conceptual categories are linked in different systems of knowledge. The concept of kuleana inspired this suggestion, as it encompasses two concepts responsibility and rights - that are otherwise seen, especially within Western traditions of thought, as quite distinct. From a Hawaiian perspective, it would not make sense to consider your right to engage

with a place without also considering your responsibility to that place. Future relational values research could consider concepts that are separate in one system of knowledge and interdependent in another.

\subsection{Relational and social values in the context of Hawaiian values}

As mentioned above, relational values and social values have both arisen somewhat recently as value conceptions that aim to facilitate consideration of values in sustainability-related decision-making. The two conceptions share many important tenets, yet they also differ in multiple ways. Below we draw on our results to offer reflections on how the two concepts compare.

First, social values can be conceived of as values that relate to value to society, or "benefit, worth, or importance to society as a whole" (Kenter et al. 2015, p. 88). This perspective-that values produce a beneficial output-can have an instrumental flavor. Because it focuses on non-instrumental 
relationships (Muraca 2016; Chan et al. 2016), the relational values framework can help to distinguish between instrumental and non-instrumental understandings of benefit, worth, or importance to society as a whole. Moreover, relational values help to express the importance of different and sometimes conflictual types of relations; they thus enable different perspectives on what is considered 'part of society' or 'society as a whole'. Some relational values can, for example, refer to relationships that need not have an obviously societal dimension (see Figure 1). In some cases, relational values pertain to relationships that matter to a few people (Chan et al. 2018). This means that relational values can highlight what matters to marginalized communities - and what matters for these communities might contrast "benefits, worth, or importance to society as a whole" (Kenter et al. 2015, p. 88). The concept of mālama provides an example. As noted in the results, some long-time residents of Hawai'i believe that many people using the term mālama today may not "truly get it." Mālama is a concept deeply integrated with relationship with place - a particular kind of love-infused and often use-based relationship with place. The relationship-based meaning of the term may not resonate with, or even make sense to, some people (likely those who lack deep Hawaiian understanding of people-place relationships - such as, quite possibly, all but one author of this paper).

Second, an even more fundamental distinction between relational values and social values is the understanding of society as formed only by human beings. The relational values framework questions the strict separation between 'society' and 'nature;' a core aspect of relational values is to make space for perspectives that understand society as not limited to a human collective. The Hawaiian values described above integrate human and more-than-human collectives. They apply equally to human and more-than-human relationships. In Hawaiian contexts, values that in many waysconform to definitions of social values pertain to both humans and more-than-humans: the latter are considered as community members and are included in consideration of "value to society." Kinship relations, which were one inspiration for the relational values concept (Gould et al. 2015; Himes and Muraca 2018), are central here: for many Hawaiians, a conversation about value could not appropriately address value to only one part of the 'ohana (family). 'Aumākua offer a powerful example of the permeable boundary between human and more-than-human, and the role of values in that human-more-than-human collective: 'aumākua are ancestors that appear as particular animals, and they remind people of important values. In a Latourian mode of thinking, what qualifies as 'social' is "not limited to human beings, but it is extended to all beings that influence each other, that are perceptive, in some way, of each other" (Schinkel 2007, p. 713). This perspective seems to be especially, though not exclusively, important in non-Western traditions (Descola 1996; Haraway 2016). Though the call to extend the moral realm beyond the human domain appears in some Western traditions (e.g., Leopold's (1966) 'Land Ethic'), that work still assumes a society-nature dualism. Hawaiian perspectives can help to improve the use and definition of relational values on this point. They might also help to reframe social values; social valuesfocused scholars have begun to explore how to include more-than-human entities within conceptions of "the common good" (O'Connor and Kenter, this issue).

Third, the deeply relational natural of relational values questions distinctions of self- vs. otheroriented values (and other-oriented values are one permutation of social values (Kenter et al. 2015)). This is because, as the discussion of feminist care ethics in the introduction noted, many relationships have both self-regarding and other-regarding aspects (e.g., according to feminist care ethics, "persons in caring relations are acting for self-and-other-together" (Held 2006, p. 540)). Feminist care ethics 
considers "persons as relational and interdependent," so that "morally and epistemologically [...] our relations are part of what constitute our identity" (Held 2006, p. 542). In such a relational understanding of identity, the distinction between self- and other-regarding values does not make sense. The concept of pono provides an example. Pono is used to describe balance and righteousness in ways that can transcend self/other distinctions: an individual cannot be pono or live pono without considering relations with others, because the concept is rooted in understandings of interdependence. Pono is neither an other-regarding value nor a self-regarding value; it is a value whose manifestation necessarily integrates self and others.

Fourth, and closely related to the third point above, all of the Hawaiian values that emerged in our inquiry emphasize two-way interaction, with reciprocity as central. Such reciprocal relations are a key component of the relational values concept. Much recent scholarship related to ecosystem services also emphasizes the importance of two-way interaction, as opposed to the one-way interaction described by the services metaphor (Raymond et al. 2013, 2018; Muraca 2016; Cooper et al. 2016); the absence of reciprocity is a primary critique of the cultural ecosystem services concept (Comberti et al. 2015). Mālama ( care), for example, differs from 'helping' in that it implies a reaction to responses of the cared-for entity. The discourse on social values demonstrates that some social values certainly encompass the idea of reciprocal interaction (Cooper et al. 2016; Edwards et al. 2016), but this reciprocity is not necessarily central to the social values definition or framework.

Fifth, the social values and relational values frameworks address valuation processes differently, although with some overlapping ground and possible fruitful integrations. The social values concept arose largely in response to an overwhelming focus on individual valuation approaches; as a result, it focuses strongly on elicitation processes. The social values framework suggests that elicitation processes should not only aggregate individual responses, but also include ways to understand collective values, such as through deliberative valuation (Raymond et al. 2014; Kenter et al. 2016). The relational values framework refers less often to elicitation processes, and emphasizes the importance of values expression beyond formal valuation contexts (Tadaki et al. 2017; Chan et al. 2018). References to valuation in the relational values literature emphasize that individuals exist within a web of relationships and are constituted through and by those relationships: with other humans, with more-than-human others, and with the world generally (Muraca 2016; Himes and Muraca 2018). The articulation of this horizon is "mediated, influenced, and co-determined by socially shared" values (Himes and Muraca 2018, p. 2), and it manifests via different, and sometimes incommensurable, language. This implies not only that valuation is socially imbued, but also that when it comes to elicitation, pluralistic approaches are necessary to access the diversity of valuation languages (Himes and Muraca 2018). Thus far, however, empirical studies of relational values have mostly used surveys and aggregated individual responses to understand (rather than valuate) relational values (Klain et al. 2017; Chapman et al. 2019). Hawaiian perspectives, as mentioned above, do not traditionally discuss values explicitly, which could complicate both explicit value deliberation and individual-based elicitation methods. Methods to understand these values might need to include alternative participatory approaches that are more flexible with respect to local models of nature (Escobar 2008) and more sensitive to embodied practices. Here, Hawaiian practices may offer insight into other potential elicitation techniques, via types of interaction infused with value. As we address below, different types of communal approaches may be 
crucial for eliciting some relational values. The social values framework offers important guidance and insight in this regard, and, as discussed below, Hawaiian perspectives may expand options even further.

\subsection{Implications for sustainability research and practice - ho'oponopono and alternatives to deliberation}

Hawaiian approaches to values offer insight into tools and processes that intend to better include values in sustainability contexts. In our discussion of this insight, we focus on two areas: values as lived (or embodied), and modified forms of group or deliberative processes.

Many frameworks for eliciting values prioritize explicit verbal expression of those values (Wilson and Howarth 2002; Kenter et al. 2016). Yet in Hawai'i, many people believe that "you see values in people's actions," rather than discuss them. This idea is also found in other Indigenous contexts (Brear et al., this issue). There is some danger that deliberative approaches, if they assume that all meaningful ideas will arise in discussion, might miss crucial perspectives. To address this challenge, we see promise in deeper consideration of how "lived values" might integrate with explicit forms of value articulation. An important caveat, however, is that these lived values too will be limited - contexts may impede people from expressing their values, especially for marginalized communities in postcolonial contexts; for this reason, local communities should, whenever possible, co-determine the conditions of knowledge exchange (Chambers 1997; Whyte 2018b).

In addition to assuming explicit verbal expression of "what matters," traditional deliberative approaches prioritize rational argument (Habermas 1984) over other forms of value articulation. More recent approaches to deliberative methods focus on value formation and transformation through dialogue not limited to rational arguments; arts-led-dialogue provides one example (Edwards et al. 2016). Hawaiian approaches offer an interesting alternative deliberation method. A primary Hawaiian form of dispute resolution is ho'oponopono - the practice of creating pono (balance, righteousness). ${ }^{7}$ This discourse-based practice of dispute resolution emphasizes the importance of true, deep listening to others' perspectives, rather than promoting one's own; one interpretation of this practice is that it builds and consolidates relationships. This primacy of listening to people's stories and explanations rather than talking - offers an interesting permutation on deliberative methods as often described in the sustainability literature. It also mirrors approaches in other contexts - for example, the West African 'palaver' is a form of dispute resolution that foregrounds narrative and emotion-based communication (Scheid 2011). Approaches that foreground listening, emotion, and experience (rather than argumentation), would shift the focus, and relatedly the tenor, of deliberative processes in ways that

\footnotetext{
${ }^{7}$ In stories from ancient Hawai' $i$, process does not figure prominently in discussions of values. The society was hierarchical, not democractic in a Western sense. But after the arrival of missionaries, ho'oponopono - the practice of creating pono - was developed (Chun 2011). The history of ho'oponopono is complex, but to many, it blends an emphasis on Hawaiian ideals with more discourse-based practices imported by missionaries. It became an important and much-celebrated part of the culture that has received attention from a variety of Western sources, from scholarly efforts to make social work more culturally responsive (Coates et al. 2006) to popular culture calls for non-violent communication (evident in, for instance, URLs of websites that describe the process, e.g., http://www.laughteronlineuniversity.com/practice-hooponopono-four-simple-steps/; https://upliftconnect.com/hawaiian-practice-of-forgiveness/; http://www.presentlove.com/hooponopono/).
} 
might prove meaningful. These approaches may inform important new ways of dealing with value conflicts, which are at the root of many environmental conflicts (Martinez-Alier 2003) and play a major role in sustainability decision-making. Perhaps new methods - for instance, for deliberation and for dealing with value conflicts - could grow from this ho'oponopono concept of deep listening in a righteous, balanced, and open - i.e., in a pono - way.

\subsection{Conclusion}

We discuss how five Hawaiian values resonate with the relational values concept, and use these findings to inform the interface of relational values and social values. Our deep dive into one Indigenous perspective suggests that though social values and relational values conceptions both add useful elements to the discourse about values, the relational values concept may be particularly well positioned to represent elements often important to indigenous worldviews - elements such as reciprocity, balance, and extension of "society" beyond human beings. We are eager to see how scholarship on these multiple value conceptions develops, and we hope that as this occurs, indigenous perspectives continue to inform this work in central and meaningful ways.

\section{Acknowledgements:}

The 'olelo in the title is number 620 in 'Olelo No'eau, a book of Hawaiian sayings compiled by Mary Kawena Pukui (1997); we are grateful to Ms. Pukui for collecting and recording thousands of such sayings. We thank the editors of this special feature, particularly Jasper Kenter, who provided extremely thoughtful and detailed comments, and three anonymous reviewers; the feedback greatly improved our manuscript. We also thank Leah Bremer for finding and photographing examples of how Hawaiian 'values' terms are used in Hawai'i today.

\section{Works Cited}

Aikau HK, Goodyear-Ka'ōpua N, Silva NK (2016) The practice of kuleana: Reflections on critical indigenous studies through trans-indigenous exchange. In: Aileen Moreton-Robinson (ed) Critical Indigenous Studies: Engagements in First World Locations. University of Arizona Press, Tucson, Arizona

Anderson E (1993) Value in Ethics and Economics. Harvard University Press, Cambridge, Massachusetts

Arias-Arévalo P, Gómez-Baggethun E, Martín-López B, Pérez-Rincón M (2018) Widening the Evaluative Space for Ecosystem Services: A Taxonomy of Plural Values and Valuation Methods. https://www.ingentaconnect.com/content/whp/ev/2018/00000027/00000001/art00004. Accessed 15 Mar 2019 
Arias-Arévalo P, Martín-López B, Gómez-Baggethun E (2017) Exploring intrinsic, instrumental, and relational values for sustainable management of social-ecological systems. Ecology and Society 22:43

Balvanera P, Calderón-Contreras R, Castro AJ, et al (2017) Interconnected place-based social-ecological research can inform global sustainability. Current Opinion in Environmental Sustainability 29:17. doi: 10.1016/j.cosust.2017.09.005

Bang M, Medin DL, Atran S (2007) Cultural mosaics and mental models of nature. Proceedings of the National Academy of Sciences of the United States of America 104:13868-13874. doi: 10.1073/pnas.0706627104

Batavia C, Nelson M (2017) For goodness sake! What is intrinsic value and why should we care? Biological Conservation 209:366-376. doi: 10.1016/j.biocon.2017.03.003

Braun V, Clarke V (2006) Using thematic analysis in psychology. Qualitative research in psychology 3:77101

Cajete G (1994) Look to the mountain: An ecology of indigenous education. Kivaki Press, Asheville, NC

Chambers R (1997) Whose reality counts: Putting the first last. Intermediate Technology Publications, London

Chan C Kai MA, Pascual U, Gould R (2018) Relational values: What are they, and what's all the fuss about? Current Opinion in Environmental Sustainability (online preview)

Chan KMA, Balvanera P, Benessaiah K, et al (2016) Opinion: Why protect nature? Rethinking values and the environment. Proceedings of the National Academy of Sciences 113:1462-1465. doi: 10.1073/pnas.1525002113

Chapman M, Satterfield T, Chan KMA (2019) When value conflicts are barriers: Can relational values help explain farmer participation in conservation incentive programs? Land Use Policy 82:464-475. doi: 10.1016/j.landusepol.2018.11.017

Chun MN (2011) No Na Mamo: Traditional and contemporary Hawaiian beliefs and practices. University of Hawai'i Press

Coates J, Gray M, Hetherington T (2006) An 'ecospiritual'perspective: finally, a place for indigenous approaches. British Journal of Social Work 36:381-399

Comberti C, Thornton TF, Wyllie de Echeverria V, Patterson T (2015) Ecosystem services or services to ecosystems? Valuing cultivation and reciprocal relationships between humans and ecosystems. Global Environmental Change 34:247-262. doi: 10.1016/j.gloenvcha.2015.07.007 
Cooper N, Brady E, Steen H, Bryce R (2016) Aesthetic and spiritual values of ecosystems: Recognising the ontological and axiological plurality of cultural ecosystem 'services.' Ecosystem Services 21, Part B:218-229. doi: 10.1016/j.ecoser.2016.07.014

de la Cadena M (2018) Uncommoning nature: stories from the Anthropo-not-seen. Revista do Instituto de Estudos Brasileiros 95-117

Descola P (1996) In the Society of Nature. Cambridge University Press

Díaz S, Pascual U, Stenseke M, et al (2018) Assessing nature's contributions to people. Science 359:270. doi: 10.1126/science.aap8826

Edwards DM, Collins TM, Goto R (2016) An arts-led dialogue to elicit shared, plural and cultural values of ecosystems. Ecosystem Services 21:319-328. doi: 10.1016/j.ecoser.2016.09.018

Escobar A (2008) Territories of difference: place, movements, life, redes. Duke University Press Books, Durham

Fish R, Church A, Winter M (2016) Conceptualising cultural ecosystem services: A novel framework for research and critical engagement. Ecosystem Services 21, Part B:208-217. doi: 10.1016/j.ecoser.2016.09.002

Gaston KJ, Aimé E, Chan KMA, et al (2018) People and Nature-A journal of relational thinking. People and Nature 0: doi: 10.1002/pan3.7

Gilligan C (1993) In a Different Voice: Psychological Theory and Women's Development, 6th edn. Harvard University Press, Cambridge, MA

Gómez-Baggethun E, Martín-López B (2015) Ecological economics perspectives on ecosystem services valuation. In: Martínez Alier J, Muradian R (eds) Handbook of ecological economics. Edward Elgar Publishing, Cheltenham, UK, pp 260-282

Gould RK, Ardoin NM, Hashimoto JK (2010) 'Mālama the 'āina, Mālama the people on the 'āina': The reaction to avatar in Hawai'i. Journal for the Study of Religion, Nature and Culture 4:425-456

Gould RK, Ardoin NM, Woodside U, et al (2014) The forest has a story: cultural ecosystem services in Kona, Hawai'i. Ecology and Society 19:. doi: 10.5751/ES-06893-190355

Gould RK, Klain SC, Ardoin NM, et al (2015) A Protocol for Eliciting Nonmaterial Values Through a Cultural Ecosystem Services Frame. Conservation Biology 29:575-586. doi: 10.1111/cobi.12407

Graeber D (2014) On the moral grounds of economic relations: A Maussian approach. Journal of Classical Sociology 14:65-77. doi: 10.1177/1468795X13494719

Habermas J (1984) The theory of communicative action. Beacon press, Boston, MA 
Haraway DJ (2016) Staying with the trouble: Making kin in the Chthulucene. Duke University Press

Held V (2006) The ethics of care: Personal, political, and global. In: Copp D (ed) The Oxford Handbook of Ethical Theory. Oxford University Press, Oxford, UK

Higashi Kanahele K (2007) I Ke Poo O Ka Ohu (The Source of Mist)

Himes A, Muraca B (2018) Relational values: the key to pluralistic valuation of ecosystem services. Current Opinion in Environmental Sustainability 35:1-7. doi: 10.1016/j.cosust.2018.09.005

Jax K, Calestani M, Chan KM, et al (2018) Caring for nature matters: a relational approach for understanding nature's contributions to human well-being. Current opinion in environmental sustainability

Ka'imipono MAK, Kahumoku WI (2006) Makawalu: Standards, Curriculum, and Assessment for Literature through an Indigenous Perspective. In: Hülili: Multidisciplinary Research on Hawaiian WellBeing. Kamehameha Schools, Honolulu, HI

Kanahele G (1979) The Hawaiian Renaissance

Kanahele GH (1992) Ku kanaka stand tall: A search for Hawaiian values. University of Hawaii Press

Kanahele P (2009) Papakū Makawalu Parts 1 and 2. Keauhou, Hawai'i

Kanaka'ole Kanahele P, Wise KW (n.d.) Ka Honua Ula (The Living Earth)

Kenter J, Raymond C, Van Riper C, et al (2019) Loving the mess: Navigating diversity and conflict in social values for sustainability. Sustainability Science

Kenter JO, Bryce R, Christie M, et al (2016) Shared values and deliberative valuation: Future directions. Ecosystem Services 21:358-371. doi: 10.1016/j.ecoser.2016.10.006

Kenter JO, O'Brien L, Hockley N, et al (2015) What are shared and social values of ecosystems? Ecological Economics 111:86-99. doi: 10.1016/j.ecolecon.2015.01.006

Kimmerer R (2013) Braiding sweetgrass: indigenous wisdom, scientific knowledge and the teachings of plants. Milkweed Editions, Minneapolis, MN

King T (1990) All my relations: An anthology of contemporary Canadian Native fiction. McClelland \& Stewart, Toronto

Klain SC, Olmsted P, Chan KMA, Satterfield T (2017) Relational values resonate broadly and differently than intrinsic or instrumental values, or the New Ecological Paradigm. PLOS ONE 12:e0183962. doi: 10.1371/journal.pone.0183962 
Leopold A (1966) A Sand County Almanac. Oxford University Press, New York, NY

Linnekin JS (1983) Defining Tradition: Variations on the Hawaiian Identity. American Ethnologist 10:241252

Maly K (2001) Mälama pono i ka 'äina: An overview of the Hawaiian cultural landscape

Martinez-Alier J (2003) The Environmentalism of the poor: a study of ecological conflicts and valuation. Edward Elgar Publishing

Mauss M (2002) The gift: The form and reason for exchange in archaic societies. Routledge

McGregor DP (1996) An introduction to the Hoa'äina and their rights. Hawaiian Journal of History 30:127

McShane K (2012) Some Challenges for Narrative Accounts of Value. Ethics and the Environment 17:4569. doi: 10.2979/ethicsenviro.17.1.45

Medin DL, Bang M (2013) Who's asking?: Native science, Western science, and science education. The MIT Press

Muraca B (2016) Relational Values: A Whiteheadian Alternative for Environmental Philosophy and Global Environmental Justice. Balkan Journal of Philosophy 8:19-38

Nakoa K-ARK, Wright EK (2015) Kanaka'Ōiwi Methodologies: Moolelo and Metaphor. University of Hawai'i Press

Pascua P, McMillen H, Ticktin T, et al (2017) Beyond services: A process and framework to incorporate cultural, genealogical, place-based, and indigenous relationships in ecosystem service assessments. Ecosystem Services 26:465-475. doi: 10.1016/j.ecoser.2017.03.012

Pascual U, Balvanera P, Díaz S, et al (2017) Valuing nature's contributions to people: the IPBES approach. Current Opinion in Environmental Sustainability 26-27:7-16. doi: 10.1016/j.cosust.2016.12.006

Peters MA, Mika CT (2017) Aborigine, Indian, indigenous or first nations? Taylor \& Francis

Pukui MK (1997) 'Ōlelo No'eau: Hawaiian Proverbs \& Poetical Sayings. Bishop Museum Press, Honolulu, $\mathrm{HI}$

Pukui MK, Elbert SH (1986) Hawaiian Dictionary. University of Hawai'i Press, Honolulu, HI

Pukui MK, Haertig EW, Lee CA (1972) Ulukau: Nānā i ke kumu (Look to the source). Vol. II. Hui Hānai, Honolulu, $\mathrm{HI}$ 
Rawluk A, Ford R, Anderson N, Williams K (2019) Exploring multiple dimensions of values and valuing: a conceptual framework for mapping and translating values for social-ecological research and practice. Sustainability Science 1-14

Raymond CM, Giusti M, Barthel S (2018) An embodied perspective on the co-production of cultural ecosystem services: toward embodied ecosystems. Journal of Environmental Planning and Management 61:778-799. doi: 10.1080/09640568.2017.1312300

Raymond CM, Kenter JO, Plieninger T, et al (2014) Comparing instrumental and deliberative paradigms underpinning the assessment of social values for cultural ecosystem services. Ecological Economics 107:145-156. doi: 10.1016/j.ecolecon.2014.07.033

Raymond CM, Singh GG, Benessaiah K, et al (2013) Ecosystem Services and Beyond: Using Multiple Metaphors to Understand Human-Environment Relationships. BioScience 63:536-546. doi: 10.1525/bio.2013.63.7.7

Sai DK (2018) The Hawaiian Kingdom

Sai DK (2008) The American occupation of the Hawaiian kingdom: Beginning the transition from occupied to restored state. University of Hawai'i

Saxena AK, Chatti D, Overstreet K, Dove MR (2018) From moral ecology to diverse ontologies: relational values in human ecological research, past and present. Current Opinion in Environmental Sustainability 35:54-60. doi: 10.1016/j.cosust.2018.10.021

Scheid AF (2011) Under the Palaver Tree: Community Ethics for Truth-Telling and Reconciliation. Journal of the Society of Christian Ethics 31:17-36. doi: 0.5840/jsce201131128

Schinkel W (2007) Sociological Discourse of the Relational: The Cases of Bourdieu \& Latour. The Sociological Review 55:707-729. doi: 10.1111/j.1467-954X.2007.00749.x

Sheremata M (2018) Listening to relational values in the era of rapid environmental change in the Inuit Nunangat. Sustainability Challenges: Relational Values 35:75-81. doi:

10.1016/j.cosust.2018.10.017

Silva NK (2017) The Power of the Steel-tipped Pen: Reconstructing Native Hawaiian Intellectual History. Duke University Press

Tadaki M, Sinner J, Chan KMA (2017) Making sense of environmental values: a typology of concepts. Ecology and Society 22:. doi: 10.5751/ES-08999-220107

Tallis H, Lubchenco J (2014) Working together: A call for inclusive conservation. Nature 515: 
Taylor B (2010) Dark green religion: Nature spirituality and the planetary future. University of California Press, Berkeley, California, USA

Tengö M, Brondizio ES, Elmqvist T, et al (2014) Connecting Diverse Knowledge Systems for Enhanced Ecosystem Governance: The Multiple Evidence Base Approach. AMBIO 43:579-591. doi: 10.1007/s13280-014-0501-3

Tengö M, Hill R, Malmer P, et al (2017) Weaving knowledge systems in IPBES, CBD and beyond-lessons learned for sustainability. Current Opinion in Environmental Sustainability 26-27:17-25. doi: 10.1016/j.cosust.2016.12.005

Tinker T (2015). In: Omar IA, Duffey MK (eds) Peacemaking and the challenge of violence in world religions. John Wiley \& Sons, New York

Vaismoradi M, Turunen H, Bondas T (2013) Content analysis and thematic analysis: Implications for conducting a qualitative descriptive study. Nursing \& health sciences 15:398-405

Vaughan MB (2014) 'Āina (Land), That Which Feeds: Researching Community Based Natural Resource Management at Home. Journal of Research Practice 10:19

Vaughan MB (2018) Kaiāulu: Gathering Tides. Oregon State University Press, Corvallis, Oregon

Vaughan MB, Thompson B, Ayers AL (2017) Pāwehe Ke Kai a'o Hā'ena: Creating State Law based on Customary Indigenous Norms of Coastal Management. Society \& Natural Resources 30:31-46. doi: 10.1080/08941920.2016.1196406

Vaughan MB, Vitousek PM (2013) Mahele: Sustaining Communities through Small-Scale Inshore Fishery Catch and Sharing Networks. Pacific Science 67:329-344. doi: 10.2984/67.3.3

Viveiros de Castro E (2004a) Perspectival anthropology and the method of controlled equivocation. Tipití: Journal of the Society for the Anthropology of Lowland South America 2:1

Viveiros de Castro EB (2004b) Exchanging perspectives: the transformation of objects into subjects in Amerindian ontologies. Common knowledge 10:463-484

Warren K (2000) Ecofeminist philosophy: A western perspective on what it is and why it matters. Rowman \& Littlefield

Washinawatok K, Rasmussen C, Bang M, et al (2017) Children's Play with a Forest Diorama as a Window into Ecological Cognition. Journal of Cognition and Development 18:617-632. doi: $10.1080 / 15248372.2017 .1392306$

Whyte K (2018a) Settler Colonialism, Ecology, and Environmental Injustice 
Whyte K (2018b) What Do Indigenous Knowledges Do For Indigenous Peoples? In: Nelson MK, Shilling D (eds) Traditional Ecological Knowledge: Learning from Indigenous Practices of Environmental Sustainability. Edited by M.K. Nelson and D. Shilling. Cambridge University Press, Cambridge, U.K., pp 57-82

Whyte K, Holtgren M, Ogren S (2015) Renewing Relatives: Nmé (Sturgeon) Stewardship in a Shared Watershed. Tales of hope and caution in environmental justice

Wilson MA, Howarth RB (2002) Discourse-based valuation of ecosystem services: Establishing fair outcomes through group deliberation. Ecological Economics 41:431-443

Anderson E (1993) Value in Ethics and Economics. Harvard University Press, Cambridge, Massachusetts

Arias-Arévalo P, Gómez-Baggethun E, Martín-López B, Pérez-Rincón M (2018) Widening the Evaluative Space for Ecosystem Services: A Taxonomy of Plural Values and Valuation Methods. https://www.ingentaconnect.com/content/whp/ev/2018/00000027/00000001/art00004. Accessed 15 Mar 2019

Arias-Arévalo P, Martín-López B, Gómez-Baggethun E (2017) Exploring intrinsic, instrumental, and relational values for sustainable management of social-ecological systems. Ecology and Society 22:43

Balvanera P, Calderón-Contreras R, Castro AJ, et al (2017) Interconnected place-based social-ecological research can inform global sustainability. Current Opinion in Environmental Sustainability 29:17. doi: 10.1016/j.cosust.2017.09.005

Bang M, Medin DL, Atran S (2007) Cultural mosaics and mental models of nature. Proceedings of the National Academy of Sciences of the United States of America 104:13868-13874. doi: 10.1073/pnas.0706627104

Batavia C, Nelson M (2017) For goodness sake! What is intrinsic value and why should we care? Biological Conservation 209:366-376. doi: 10.1016/j.biocon.2017.03.003

Braun V, Clarke V (2006) Using thematic analysis in psychology. Qualitative research in psychology 3:77101

Cajete G (1994) Look to the mountain: An ecology of Indigenous education. Kivaki Press, Asheville, NC

Chan C Kai MA, Pascual U, Gould R (2018) Relational values: What are they, and what's all the fuss about? Current Opinion in Environmental Sustainability (online preview) 
Chan KMA, Balvanera P, Benessaiah K, et al (2016) Opinion: Why protect nature? Rethinking values and the environment. Proceedings of the National Academy of Sciences 113:1462-1465. doi:

10.1073/pnas.1525002113

Chapman M, Satterfield T, Chan KMA (2019) When value conflicts are barriers: Can relational values help explain farmer participation in conservation incentive programs? Land Use Policy 82:464-475. doi: 10.1016/j.landusepol.2018.11.017

Chun MN (2011) No Na Mamo: Traditional and contemporary Hawaiian beliefs and practices. University of Hawai'i Press

Coates J, Gray M, Hetherington T (2006) An 'ecospiritual'perspective: finally, a place for Indigenous approaches. British Journal of Social Work 36:381-399

Comberti C, Thornton TF, Wyllie de Echeverria V, Patterson T (2015) Ecosystem services or services to ecosystems? Valuing cultivation and reciprocal relationships between humans and ecosystems. Global Environmental Change 34:247-262. doi: 10.1016/j.gloenvcha.2015.07.007

Cooper N, Brady E, Steen H, Bryce R (2016) Aesthetic and spiritual values of ecosystems: Recognising the ontological and axiological plurality of cultural ecosystem 'services.' Ecosystem Services 21, Part B:218-229. doi: 10.1016/j.ecoser.2016.07.014

de la Cadena M (2018) Uncommoning nature: stories from the Anthropo-not-seen. Revista do Instituto de Estudos Brasileiros 95-117

Descola P (1996) In the Society of Nature. Cambridge University Press

Díaz S, Pascual U, Stenseke M, et al (2018) Assessing nature's contributions to people. Science 359:270. doi: 10.1126/science.aap8826

Escobar A (2008) Territories of difference: place, movements, life, redes. Duke University Press Books, Durham

Fish R, Church A, Winter M (2016) Conceptualising cultural ecosystem services: A novel framework for research and critical engagement. Ecosystem Services 21, Part B:208-217. doi: 10.1016/j.ecoser.2016.09.002

Gaston KJ, Aimé E, Chan KMA, et al (2018) People and Nature-A journal of relational thinking. People and Nature 0: doi: 10.1002/pan3.7

Gilligan C (1993) In a Different Voice: Psychological Theory and Women's Development, 6th edn. Harvard University Press, Cambridge, MA 
Gómez-Baggethun E, Martín-López B (2015) Ecological economics perspectives on ecosystem services valuation. In: Martínez Alier J, Muradian R (eds) Handbook of ecological economics. Edward Elgar Publishing, Cheltenham, UK, pp 260-282

Gould RK, Ardoin NM, Hashimoto JK (2010) 'Mālama the 'āina, Mālama the people on the 'āina': The reaction to avatar in Hawai'i. Journal for the Study of Religion, Nature and Culture 4:425-456

Gould RK, Ardoin NM, Woodside U, et al (2014) The forest has a story: cultural ecosystem services in Kona, Hawai'i. Ecology and Society 19:. doi: 10.5751/ES-06893-190355

Gould RK, Klain SC, Ardoin NM, et al (2015) A Protocol for Eliciting Nonmaterial Values Through a Cultural Ecosystem Services Frame. Conservation Biology 29:575-586. doi: 10.1111/cobi.12407

Graeber D (2014) On the moral grounds of economic relations: A Maussian approach. Journal of Classical Sociology 14:65-77. doi: 10.1177/1468795X13494719

Habermas J (1984) The theory of communicative action. Beacon press, Boston, MA

Held V (2006) The ethics of care: Personal, political, and global. In: Copp D (ed) The Oxford Handbook of Ethical Theory. Oxford University Press, Oxford, UK

Higashi Kanahele K (2007) I Ke Poo O Ka Ohu (The Source of Mist)

Himes A, Muraca B (2018) Relational values: the key to pluralistic valuation of ecosystem services. Current Opinion in Environmental Sustainability 35:1-7. doi: 10.1016/j.cosust.2018.09.005

Jax K, Calestani M, Chan KM, et al (2018) Caring for nature matters: a relational approach for understanding nature's contributions to human well-being. Current opinion in environmental sustainability

Ka'imipono MAK, Kahumoku WI (2006) Makawalu: Standards, Curriculum, and Assessment for Literature through an Indigenous Perspective. In: Hülili: Multidisciplinary Research on Hawaiian WellBeing. Kamehameha Schools, Honolulu, HI

Kanahele G (1979) The Hawaiian Renaissance

Kanahele GH (1992) Ku kanaka stand tall: A search for Hawaiian values. University of Hawaii Press

Kanahele P (2009) Papakū Makawalu Parts 1 and 2. Keauhou, Hawai'i

Kanaka'ole Kanahele P, Wise KW (n.d.) Ka Honua Ula (The Living Earth)

Kenter J, Raymond C, Van Riper C, et al (2019) Loving the mess: Navigating diversity and conflict in social values for sustainability. Sustainability Science 
Kenter JO, Bryce R, Christie M, et al (2016) Shared values and deliberative valuation: Future directions. Ecosystem Services 21:358-371. doi: 10.1016/j.ecoser.2016.10.006

Kenter JO, O'Brien L, Hockley N, et al (2015) What are shared and social values of ecosystems? Ecological Economics 111:86-99. doi: 10.1016/j.ecolecon.2015.01.006

Kimmerer R (2013) Braiding sweetgrass: Indigenous wisdom, scientific knowledge and the teachings of plants. Milkweed Editions, Minneapolis, MN

King T (1990) All my relations: An anthology of contemporary Canadian Native fiction. McClelland \& Stewart, Toronto

Kittay EF, Feder EK (2003) The subject of care: feminist perspectives on dependency. Rowman \& Littlefield Publishers

Klain SC, Olmsted P, Chan KMA, Satterfield T (2017) Relational values resonate broadly and differently than intrinsic or instrumental values, or the New Ecological Paradigm. PLOS ONE 12:e0183962. doi: 10.1371/journal.pone.0183962

Leopold A (1966) A Sand County Almanac. Oxford University Press, New York, NY

Linnekin JS (1983) Defining Tradition: Variations on the Hawaiian Identity. American Ethnologist 10:241252

Maly K (2001) Mälama pono i ka 'äina: An overview of the Hawaiian cultural landscape

Mauss M (2002) The gift: The form and reason for exchange in archaic societies. Routledge

McGregor DP (1996) An introduction to the Hoa'äina and their rights. Hawaiian Journal of History 30:127

McShane K (2012) Some Challenges for Narrative Accounts of Value. Ethics and the Environment 17:4569. doi: 10.2979/ethicsenviro.17.1.45

Medin DL, Bang M (2013) Who's asking?: Native science, Western science, and science education. The MIT Press

Muraca B (2016) Relational Values: A Whiteheadian Alternative for Environmental Philosophy and Global Environmental Justice. Balkan Journal of Philosophy 8:19-38

Nakoa K-ARK, Wright EK (2015) Kanaka'Ōiwi Methodologies: Moolelo and Metaphor. University of Hawai'i Press 
Pascua P, McMillen H, Ticktin T, et al (2017) Beyond services: A process and framework to incorporate cultural, genealogical, place-based, and Indigenous relationships in ecosystem service assessments. Ecosystem Services 26:465-475. doi: 10.1016/j.ecoser.2017.03.012

Pascual U, Balvanera P, Díaz S, et al (2017) Valuing nature's contributions to people: the IPBES approach. Current Opinion in Environmental Sustainability 26-27:7-16. doi: 10.1016/j.cosust.2016.12.006

Peters MA, Mika CT (2017) Aborigine, Indian, Indigenous or first nations? Taylor \& Francis

Pukui MK (1997) 'Ōlelo No'eau: Hawaiian Proverbs \& Poetical Sayings. Bishop Museum Press, Honolulu, $\mathrm{HI}$

Pukui MK, Elbert SH (1986) Hawaiian Dictionary. University of Hawai'i Press, Honolulu, HI

Pukui MK, Haertig EW, Lee CA (1972) Ulukau: Nānā i ke kumu (Look to the source). Vol. II. Hui Hānai, Honolulu, $\mathrm{HI}$

Rawluk A, Ford R, Anderson N, Williams K (2019) Exploring multiple dimensions of values and valuing: a conceptual framework for mapping and translating values for social-ecological research and practice. Sustainability Science 1-14

Raymond CM, Giusti M, Barthel S (2018) An embodied perspective on the co-production of cultural ecosystem services: toward embodied ecosystems. Journal of Environmental Planning and Management 61:778-799. doi: 10.1080/09640568.2017.1312300

Raymond CM, Kenter JO, Plieninger T, et al (2014) Comparing instrumental and deliberative paradigms underpinning the assessment of social values for cultural ecosystem services. Ecological Economics 107:145-156. doi: 10.1016/j.ecolecon.2014.07.033

Raymond CM, Singh GG, Benessaiah K, et al (2013) Ecosystem Services and Beyond: Using Multiple Metaphors to Understand Human-Environment Relationships. BioScience 63:536-546. doi: 10.1525/bio.2013.63.7.7

Sai DK (2018) The Hawaiian Kingdom

Sai DK (2008) The American occupation of the Hawaiian kingdom: Beginning the transition from occupied to restored state. University of Hawai'i

Saxena AK, Chatti D, Overstreet K, Dove MR (2018) From moral ecology to diverse ontologies: relational values in human ecological research, past and present. Current Opinion in Environmental Sustainability 35:54-60. doi: 10.1016/j.cosust.2018.10.021

Scheid AF (2011) Under the Palaver Tree: Community Ethics for Truth-Telling and Reconciliation. Journal of the Society of Christian Ethics 31:17-36. doi: 0.5840/jsce201131128 
Schinkel W (2007) Sociological Discourse of the Relational: The Cases of Bourdieu \& Latour. The Sociological Review 55:707-729. doi: 10.1111/j.1467-954X.2007.00749.x

Schwartz SH (1994) Are there universal aspects in the structure and contents of human values? Journal of social issues 50:19-45

Sheremata M (2018) Listening to relational values in the era of rapid environmental change in the Inuit Nunangat. Sustainability Challenges: Relational Values 35:75-81. doi: 10.1016/j.cosust.2018.10.017

Silva NK (2017) The Power of the Steel-tipped Pen: Reconstructing Native Hawaiian Intellectual History. Duke University Press

Tadaki M, Sinner J, Chan KMA (2017) Making sense of environmental values: a typology of concepts. Ecology and Society 22:. doi: 10.5751/ES-08999-220107

Tallis H, Lubchenco J (2014) Working together: A call for inclusive conservation. Nature 515:

Tengö M, Brondizio ES, Elmqvist T, et al (2014) Connecting Diverse Knowledge Systems for Enhanced Ecosystem Governance: The Multiple Evidence Base Approach. AMBIO 43:579-591. doi: 10.1007/s13280-014-0501-3

Tengö M, Hill R, Malmer P, et al (2017) Weaving knowledge systems in IPBES, CBD and beyond-lessons learned for sustainability. Current Opinion in Environmental Sustainability 26-27:17-25. doi: 10.1016/j.cosust.2016.12.005

Tinker T (2015). In: Omar IA, Duffey MK (eds) Peacemaking and the challenge of violence in world religions. John Wiley \& Sons, New York

Vaismoradi M, Turunen H, Bondas T (2013) Content analysis and thematic analysis: Implications for conducting a qualitative descriptive study. Nursing \& health sciences 15:398-405

Vaughan MB (2014) 'Āina (Land), That Which Feeds: Researching Community Based Natural Resource Management at Home. Journal of Research Practice 10:19

Vaughan MB (2018) Kaiāulu: Gathering Tides. Oregon State University Press, Corvallis, Oregon

Vaughan MB, Thompson B, Ayers AL (2017) Pāwehe Ke Kai a'o Hā'ena: Creating State Law based on Customary Indigenous Norms of Coastal Management. Society \& Natural Resources 30:31-46. doi: 10.1080/08941920.2016.1196406

Vaughan MB, Vitousek PM (2013) Mahele: Sustaining Communities through Small-Scale Inshore Fishery Catch and Sharing Networks. Pacific Science 67:329-344. doi: 10.2984/67.3.3 
Viveiros de Castro E (2004a) Perspectival anthropology and the method of controlled equivocation. Tipití: Journal of the Society for the Anthropology of Lowland South America 2:1

Viveiros de Castro EB (2004b) Exchanging perspectives: the transformation of objects into subjects in Amerindian ontologies. Common knowledge 10:463-484

Washinawatok K, Rasmussen C, Bang M, et al (2017) Children's Play with a Forest Diorama as a Window into Ecological Cognition. Journal of Cognition and Development 18:617-632. doi: 10.1080/15248372.2017.1392306

Whyte K (2018a) Settler Colonialism, Ecology, and Environmental Injustice

Whyte K (2018b) What Do Indigenous Knowledges Do For Indigenous Peoples? In: Nelson MK, Shilling D (eds) Traditional Ecological Knowledge: Learning from Indigenous Practices of Environmental Sustainability. Edited by M.K. Nelson and D. Shilling. Cambridge University Press, Cambridge, U.K., pp 57-82

Whyte K, Holtgren M, Ogren S (2015) Renewing Relatives: Nmé (Sturgeon) Stewardship in a Shared Watershed. Tales of hope and caution in environmental justice

Wilson MA, Howarth RB (2002) Discourse-based valuation of ecosystem services: Establishing fair outcomes through group deliberation. Ecological Economics 41:431-443 